\title{
The Sea of Marmara during Marine Isotope Stages 5 and 6
}

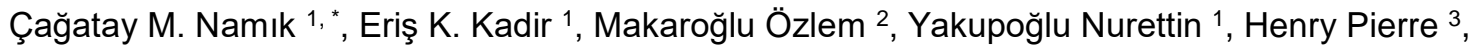 \\ Leroy Suzanne A.G. ${ }^{4}$, Uçarkuş Gülsen ${ }^{1}$, Sakınç Mehmet ${ }^{1}$, Yalamaz Burak ${ }^{1}$, Bozyiğit Cerennaz ${ }^{1}$, \\ Kende Julia ${ }^{3}$
}

1 İstanbul Technical University, EMCOL Research Centre and Dept. Geological Engineering, Ayazağa, 34469, İstanbul, Turkey

2 İstanbul-Cerrahpaşa University, Department of Geophysical Engineering, Avcılar, İstanbul, Turkey

${ }^{3}$ CEREGE (UMR7330), Aix-Marseille University, CNRS-IRD, 13330, Marseille 7, France

${ }^{4}$ Aix Marseille Univ., CNRS, Minist. Culture, LAMPEA, UMR 7269, 5 Rue du Château de l'Horloge,

13094, Aix-en-Provence, France

* Corresponding author : M. Namik Çağatay, email address : cagatay@itu.edu.tr

\begin{abstract}
:
Multi-proxy analyses and lithology of two cores, MRS-CS18 and MRS-CS27, from the İmralı Basin of the Sea of Marmara (SoM) provide novel information on environmental conditions, relative sea level, and sill depths of the straits of Bosporus and Dardanelles during the Marine Isotope Stages (MIS) 5 and 6 . The fossil and multi-proxy geochemical records show that lacustrine conditions prevailed in the SoM during most of MIS 6, from 171 to $134 \mathrm{ka} \mathrm{BP}$, and that the transition to marine conditions during Termination II took place at $\sim 134.06 \pm 1.10$ ka BP. MIS 5 interstadials a, $c$, and e witnessed the formation of three sapropels (MSAP-2, MSAP-3 and MSAP-4) under suboxic to anoxic marine conditions, whereas during stadials MIS 5b ( 94-86) and MIS 5d ( 112-105 ka BP), lacustrine and marine conditions with deposition of sediments having relatively low TOC contents $(<2 \%)$ prevailed, respectively. Consideration of the global sea level, together with the timing of the marine reconnection of the SoM during Termination II and persistence of the marine conditions during MIS 5, except for MIS $5 \mathrm{~b}$ and later part of MIS $5 \mathrm{a}$, suggests that the Dardanelles sill depth was at $\sim-75 \pm 5 \mathrm{~m}$ during the reconnection at Termination II and at $-55 \pm 5 \mathrm{~m}$ during most of MIS 5 . On similar considerations of the Black Sea marine reconnections and disruptions during the MIS 5 , a sill depth of -35 to $-40 \mathrm{~m}$ (similar to the present day depth) is indicated for the Bosporus Strait.
\end{abstract}

The SoM geochemical proxy records correlate well with the regional terrestrial and marine records and the NGRIP oxygen isotope record with its Stadial and Interstadial phases, showing the common effect of the North Atlantic climatic events triggered by the perturbations in the Atlantic Meridional Overturning Circulation. However, the amplitude of the oscillations recorded in the SoM during MIS 6 (Penultimate Glacial Period) is relatively small compared to the MIS 4 to MIS 2 (Last Glacial Period). 


\section{Highlights}

- First paper to discuss the paleoceanography of an important gateway during MIS 5 and MIS 6. First complete documentation of MIS 5 sapropels and their origin. Sea/water level changes and timing of marine connection during Termination II. Correlation of the Sea of Marmara records with regional and global records. Reporting of a new unidentified tephra.

Keywords: Sea of Marmara, Late quaternary, Marine isotope stages 5-6, Eastern Europe, Paleoceanography, Sedimentology-marine cores, Geochemical proxies, Sapropels 


\section{Introduction}

Late Quaternary paleoceanography and hydrography of the Sea of Marmara (SoM) have been extensively investigated since 1980s because of its key location between the Black Sea and the Mediterranean Sea (e.g., Stanley and Blanpied, 1980; Aksu et al., 1999, 2002; Çağatay et al., 2000, 2003; 2009, 2015; McHugh et al., 2008; Vidal et al., 2010; Eriş et al., 2007, 2011; Vardar et al., 2014). The SoM, together with the Bosporus and Dardanelles straits, known as the Turkish Straits System (TSS), is the gateway for the water-mass exchanges between its neighbouring seas (Fig. 1). Water exchange through this system is controlled by eustatic global sea-level in the Mediterranean, riverine and melt water input and water level in the Black Sea, and the sill depths of the connecting straits. Presently, a two-way water exchange exists via the TSS between the Mediterranean Sea and the Black Sea waters that constitute the lower and upper currents, respectively, with a permanent pycnocline at $\sim-25 \mathrm{~m}$ between the two (Ünlüata et al., 1990; Beşiktepe et al., 1994; Aydoğdu et al., 2018). The present sill depths of the Bosporus and Dardanelles straits are -35 and $-65 \mathrm{~m}$, respectively but might have been different during the various Quaternary stages (e.g., Ryan et al., 1997, 2003; Gökaşan et al., 2008, 2010; Çağatay et al., 2009, 2015). Moreover, the present hydrography of the SoM with the two-way water exchange might have been disrupted during the glacial periods due to eustatic sea level fall in the Mediterranean Sea and water-level changes in the Black Sea (Ryan et al., 1997, 2003, Aksu et al., 1999, 2002; Çağatay et al., 2000, 2009, 2015; Eriş et al., 2007, 2011; Hiscott et al., 2002, 2007).

The paleoceanography and hydrography of the SoM have been reasonahly well established for the marine isotope stages 1 to 4 (MIS1 to MIS4), covering the last 70 mainly because of the study of a continuous sedimentary record from the RV Marion Dufresne core MD012430, recovered from $-580 \mathrm{~m}$ on the Western High (Çağatay et al., 2015) (Fig. 1a). The study showed that the SoM was a brackish water lake from early MIS-4 to early MIS-1, disconnected from the Mediterranean Sea and became a lake with brackish to fresh waters. A significant regression took place during MIS 2, which is recorded as erosional surfaces and terraces (Aksu et al., 2002; Çağatay et al., 2009; Eriş et al., 2011).

Freshwater inputs from the Black Sea occurred during the Dansgaard-Oeschger (D-O) events (Greenland Interstadials, GI) of the MIS3 and MIS4 (Çağatay et al., 2009), that slowly 
converted the saline marine waters of the MIS5 to brackish water in the SoM (Çağatay et al., 2009; Aloisi et al., 2015). The GIs in the SoM are well expressed by high Ca (carbonate) concentrations, relatively high total organic carbon (TOC) contents, low detrital inputs and negative oxygen isotope excursions, strongly suggesting high organic productivity and high input of nutrient-rich melt waters from the European ice sheets via rivers into the Black Sea and from there into the SoM (Çağatay et al., 2015).

The lacustrine phase of SoM lasted with the initial influx of the Mediterranean Sea waters via the Dardanelles Strait at $\sim 14.7$ cal ka BP (Vidal et al., 2010). Such a hydrologic modification lasted for 1000-2000 years, and was represented by colonization of the shelf areas by euryhaline Mediterranean organisms (Çağatay et al., 2000, 2003, 2009; Aksu et al., 2002; McHugh et al., 2008; Vidal et al., 2010; Eriş et al., 2011; Vardar et al., 2014; Köprülü et al., 2016). The brackish lacustrine to marine transition with the appearance of euryhaline fauna is dated at $12.55 \pm 0.35$ cal ka BP in core MD01-2430 on the Western High (Çağatay et al., 2015) (Fig. 1b). This is followed by the establishment of the present two-layer water exchange with Black Sea through Bosporus Strait starting around 5-6 ka BP (Çağatay et al., 2000; Algan et al., 2001).

Although the hydrography and paleoceanograpy of the SoM are reasonably well known for the MIS1-MIS4, our knowledge for the older Quaternary stages are scanty and based on discontinuous records from shelf cores (Çağatay et al., 2009, 2015). A recent study by Kende et al. (in review), using multi-proxy analyses of a $20.6 \mathrm{~m}$ long core (MRS-CS22) from $551 \mathrm{~m}$ water depth on the Western High, extends the record back to within MIS5 (Fig.s. 1b and 2). However, the sequence more likely includes only the record of MIS5a to d.

In the present study, we present data from two giant piston cores MRS-CS27 (20.55 m long) and MRS-CS18 (14.20 m long) from the İmrali Basin of the SoM, extending the record back to MIS5 and MIS6, respectively (Fig. 1). The cores were recovered during the EC FP7 Marsite project cruise onboard RV Pourquoi pas? in 2014, and studied for their fossil content and geochemical and physical properties. The age-depth models of the cores were constructed using accelerated mass spectroscopy (AMS) radiocarbon dating, tephrochronology, and correlation of the SoM data with the North Greenland Ice Programme (NGRIP) $\delta^{18} \mathrm{O}$ record (Svensson et al., 2006, 2008; Rasmussen et al., 2006; Wolff et al., 2010). We specifically concentrate on the paleoceanography and hydrography of the SoM during MIS5 and MIS6, which have not been previously discussed in detail. Using the new multi-proxy data from the cores, we discuss lake/sea level changes together with the sill depths of the Bosporus (İstanbul) and Dardanelles (Çanakkale) straits, water-mass exchanges through the TSS, and the 
concomitant paleoceanographic changes in the SoM during the MIS6 and MIS5. We also compare the SoM records with the regional and global records.

The Quaternary stratigraphic records are essential not only for determination of the eustatically-controlled water mass exchanges through the Turkish Straits System, water level changes and the sill depths of Dardanelles and Bosporus straits in relation to the relative sea level changes but also for the dating of some regional seismic reflecting surfaces (e.g., Sorlien et al., 2012; Grall et al., 2013; Fig. 1), which is in turn important for determination fault slip rates and the earthquake risk assessment.

\section{Oceanographic, hydrographic and climatic settings of the Sea of Marmara}

The SoM, as part of TSS, is characterized by a two-way water exchange between the Aegean and Black seas having waters of different salinity (Fig. 1). The Mediterranean water ( $\sim 38.5 \mathrm{psu})$ and Black Sea water ( $\sim 18 \mathrm{psu})$ constitute the lower and upper currents, which are separated by a permanent pycnocline located at -25 m (Ünlüata et al., 1990; Beşiktepe et al., 1994; Chiggiato et al., 2012; Aydoğdu et al., 2018). The Black Sea has positive water balance, exporting $\sim 600 \mathrm{~km}^{3}$ of water of riverine and precipitation origin and receiving $\sim 300 \mathrm{~km}^{3}$ of Mediterranean waters through the TSS (Özsoy and Ünlüata, 1997). Some mixing between the lower and upper currents occurs during the passage through the relatively narrow Bosporus and Dardanelles straits with sill depths of $-35 \mathrm{~m}$ and $-65 \mathrm{~m}$, respectively. As a result, the salinity of the surface and bottom waters are modulated to $\sim 38$ psu and $\sim 22$ psu (Ünlüata et al., 1990; Beşiktepe et al., 1994).

The surface Black Sea waters enter the SoM as a jet from the Bosporus Strait at speeds of 1 to $1.5 \mathrm{~m} / \mathrm{s}$, forms a series of eddies, and then exit through the Dardanelles Strait, while the Mediterranean waters flow through the Dardanelles Strait and then sink to form the bottom currents with velocities less than $0.1 \mathrm{~m} / \mathrm{s}$ in the deep basins (Beşiktepe et al., 1994; Chiggiato et al., 2012). The upper and lower water masses have renewal times of 5-6 months and 6-7 years, respectively (Beşiktepe et al., 1994). The oxygen content of the bottom waters varies from 50 to than $18 \mu \mathrm{mol} / \mathrm{kg}$, with the levels decreasing from the Tekirdağ Basin in the west to the Çınarcık Basin in the east (Tryon et al., 2012).

The main drainage basin of the SoM is located to its south with the Kocasu, Gönen and Biga rivers providing $5.80 \mathrm{~km}^{3} / \mathrm{yr}$ and $2.2 \times 10^{6} \mathrm{t} / \mathrm{yr}$ of suspended sediment in the SoM (EİE, 
1993; Kazanc1 et al., 2004). The southern catchment area is mainly under the influence of the Mediterranean climate with hot and dry summers and cold and wet winters. The average winter and summer temperatures are 5 and $24^{\circ} \mathrm{C}$ and the annual precipitation varies between $\sim 500$ and $\sim 1000 \mathrm{~mm}$ (Deniz et al., 2011). The source of moisture is mainly the cyclonic Mediterranean (Cullen and deMenocal, 2000; Türkeş et al., 2009; Göktürk et al., 2011), with some contribution from the Black Sea (Fleitmann et al., 2009; Badertscher et al., 2011; Göktürk et al., 2011).

\section{Cores and analytical methods}

\subsection{Cores}

Cores MRS-CS 18 and MRS-CS 27 were recovered on board of the RV Pourquoi pas? from depths of 291 and $313 \mathrm{~m}$ in the north-eastern and western edges of the İmralı Basin, respectively (Fig. 1b, Table 1). The cores were split into halves and described at EMCOL Sedimentology laboratory, İstanbul Technical University (ITU) (Fig. 2). The working halves of the cores were sampled for total organic carbon (TOC) analysis at $5 \mathrm{~cm}$ interval but increased to a resolution of $2.5 \mathrm{~cm}$ in some parts of the sapropels. Sampling resolution for paleontological analyses was at $10 \mathrm{~cm}$ interval. For all sampling, each sample represents $1 \mathrm{~cm}$ core thickness. The archive halves were used for $\mu$-XRF (Itrax) and Geotek Multi Sensor Core Logger (MSCL) analyses.

\subsection{Paleontological analysis}

Paleontological analysis was carried out in sand size $(>63 \mu \mathrm{m})$ fraction of $5 \mathrm{~cm}^{3}$ samples. Micro- and macro-fossils, including benthic and pelagic foraminifera and bivalves, were identified and their abundances were qualitatively recorded in the samples.

\subsection{Total organic carbon (TOC) and total inorganic carbon (TIC) analyses}

The TOC content in freeze-dried samples of the cores was analysed using a Shimadzu TOC/TIC analyser at ITU-EMCOL Geochemistry Laboratory. First total carbon (TC) contents of samples were determined by the total catalytic combustion at $900{ }^{\circ} \mathrm{C}$ in the presence of purged oxygen and platinum catalyst, followed by measurement of the evolved carbon dioxide after dehumidification, using the infrared carbon dioxide detector of the analyser. Then, the total inorganic carbon (TIC) was analysed by treating the samples with $85 \%$ phosphoric acid, heating the sample to $200^{\circ} \mathrm{C}$ and measuring the evolved carbon dioxide. The TOC is calculated as the difference between TC and TIC contents. The precision of the TOC analysis with this 
method is better than $5 \%$ at a $95 \%$ confidence level. TOC is used as proxy of organic matter production and preservation.

\section{4. $\mu-X R F$ analysis}

The cores were analysed for multi-element composition at $0.5 \mathrm{~mm}$ resolution using an Itrax $\mu$-XRF Core scanner, equipped with XRF-EDS, X-Ray radiography and RGB colour camera at the ITU-EMCOL Core Analyses Laboratory (Croudace et al., 2006; Thomson et al., 2006). A fine-focus Mo X-ray tube was used as the source. The X-ray generator was operated at $60 \mathrm{kV}$, and a counting time of $20 \mathrm{~s}$ was applied. The relative elemental abundances were recorded as counts per second (cps) and their profiles were used as proxies for paleoenvironmental reconstructions. We used both element counts and element ratios; although elemental ratios are useful for normalization and elimination of systematic errors, they do not show if a change in the ratio is related to the quantity of denominator or numerator element.

Bromine is commonly used as proxy for marine organic matter and $\mathrm{Br} / \mathrm{TOC}$ as proxy for the ratio of marine/terrestrial organic matter (Mayer et al., 1981, 2007; Ziegler et al., 2008). Potassium is a proxy for detrital input, in particular illite-mica type of clays, which are mainly the weathering products of rock-forming minerals during soil formation. As, a large ion lithophile (LILE or incompatible) element, $\mathrm{K}$ is also useful in identification of tephra layers of potassium-rich alkaline affinity, which are in particular characteristic of those generated from Italian volcanic provinces (e.g., Perini et al., 2004; Wulf et al., 2004; Çağatay et al., 2015). Similarly, zircon, as high field strength element (HFSE), is useful in alkaline tephra identification (Çağatay et al., 20014, 2015). Zircon is also an indicator of coarse silt to fine sand size detrital material in marine and lake sediments. Manganese is a sensitive indicator of redox conditions; it readily precipitates as Mn-oxides in sediments deposited under oxic conditions, but remains in solution and becomes depleted in sediments of anoxic environments (e.g., Calvert, S.E., Pedersen, 1993; Thomson et al., 1995). Iron is another redox-sensitive element, which together with sulphur, forms Fe-monosulphides (i.e., greigite, mackinawite) or pyrite by authigenesis or diagenesis in organic-rich anoxic sediments (Leventhal, 1983; Berner, 1985; Lyons et al., 1997). In oxic sediments, however, Fe occurs mainly as oxyhydroxides and in clay-mineral (chlorite, illite) structures, and hence, it is considered as a detrital mineral proxy, often showing a good correlation with $\mathrm{Ti}$.

$\mathrm{Ca}$ is a proxy of endogenic carbonate production, and has been previously used in numerous marine and lacustrine environments (e.g., Cohen, 2003; Francke et al., 2016; Çağatay 
et al., 2014, 2015). Strontium is an indicator of aragonite in general. In carbonate shells, Sr-Ca ratio is an indicator of salinity and temperature in marine carbonates (e.g., Russell et al., 2004; Rosenthal, et al., 2006; Schöne et al, 2011). Sr-Ca ratio is also used to discriminate between marine and terrestrial carbonates, with marine carbonates having relatively higher ratios than those in terrestrial carbonates, because of the high concentration of $\mathrm{Sr}$ in seawater ( $\sim 70$ times the average river water concentration) (Angino et al., 1966; Palmer and Edmond, 1992).

\subsection{Geotek Multi-Sensor Core Logger analysis}

Physical properties, magnetic susceptibility and gamma density were measured at $2 \mathrm{~cm}$ resolution according to the standard procedures, using a Geotek Multi-Sensor Core Logger (MSCL) (Weaver and Schultheis, 1990).

\subsection{Chronological analysis and age-depth modelling}

\subsubsection{Accelerated mass spectroscopy (AMS) radiocarbon analysis}

AMS radiocarbon analyses on bivalve shell samples were carried out at Poznan Radiocarbon Laboratory, Poland. The shell samples were ultrasonicated to clean them from mud, washed in distilled water, and dried prior to the analysis. The ${ }^{14} \mathrm{C}$ ages of bivalve shell samples were calibrated to calendar ages using the INTCAL13 calibration curve of Reimer et al. (2013) (Table 2). A reservoir age of 400 years for the upper marine unit and 1000 years for the preceding lacustrine unit were used for the calibration (Siani, 2000; Ryan, 2007; Kwiecien et al., 2008; Soulet et al., 2011; Çağatay et al., 2015). All ages reported in this paper are reservoir corrected and calibrated to calendar years and expressed as ka BP unless otherwise stated.

\subsubsection{Age data obtained by correlation of Marmara core $\mu$-XRF Ca with NGRIP $\delta^{18} \mathrm{O}$ data}

It is well established that the GIs in the SoM and the Black Sea are characterized by endogenic carbonate precipitation, resulting from high primary production in surface waters (for details see Nowaczyk et al., 2012; Wegwerth et al., 2014; Çağatay et al., 2015). Using the correlation of positive excursions in bulk sediment-Ca data with the onsets of GIs observed in the NGRIP $\delta^{18} \mathrm{O}$ data (Svensson et al., 2006, 2008; Rasmussen et al., 2006; Wolff et al., 2010), Çağatay et al. (2015) dated the core MD01-2430 in the SoM with the GICC05 time scale. In the present study, we used the same approach and wiggle-matched (tuned) the $\mu$-XRF Ca with GIs in the NGRIP (Svensson et al., 2006, 2008) and synthetic NGIP data (Barker et al., 2011) to obtain age data for cores MRS-CS18 and MRS-CS27 (Supplementary Tables S1 and S2, Fig. $\mathrm{S} 1)$. The wiggle-matching of the SoM Ca data with NGRIP $\delta^{18} \mathrm{O}$ was made using an interactive 
computer software called "extended tool for correlation" (xtc), provided by courtesy of Norbert Nowaczyk (Deutsches GeoForschungsZentrum-GFZ, Potsdam, Germany) (Fig. 3).

We took special care to avoid the Ca peaks that are associated with Dreissena sp. $_{\text {. }}$ shell debris (e.g., 2.92-3.03 mbsf interval in core MRS-CS18) and with secondary gypsum in the sapropel layers (e.g., 6.75-6.85 mbsf interval in core MRS-CS18) (Figs. 2, 3 and 6; section 4.1.2). The Dreissena sp. shells are of aragonite composition, whereas GI-related endogenic carbonate is of calcite composition which is associated with relatively high TOC values and low $\mu$-XRF Sr counts. Despite their aragonite composition, Dreissena sp. shells are low in $\mathrm{Sr}$ because of the growth of shells in Sr-poor, fresh-brackish waters. The secondary gypsum is observed in the Fe-sulphide rich sapropel layers, and develops upon exposure of the split cores to atmospheric oxygen. Formation of the secondary gypsum starts with oxidation of $\mathrm{Fe}$ sulphides near the core surface, which produces $\mathrm{Fe}^{3+}, \mathrm{SO}_{4}{ }^{2-}$ and $\mathrm{H}^{+}$. The created acidity $\left(\mathrm{H}^{+}\right)$ dissolves carbonates and produces $\mathrm{Ca}^{2+}$ that combines with $\mathrm{SO}_{4}{ }^{2-}$ to form in situ the secondary gypsum (Çağatay, unpublished data). The $\mu$-XRF measured Ca content at a specific location at the core surface would be mainly conservative, or only slightly magnified, because of the in situ formation of gypsum at or near the surficial site of the oxidizing pyrite. The gypsum could incorporate up to $0.2 \% \mathrm{Sr}$ (Ichikuni and Musha, 1978), and hence Ca anomalies due to the presence of secondary gypsum are accompanied by relativley high $\mathrm{Sr}$ counts.

\subsubsection{Tephrochronology and sapropel age data}

Distinct tephra layers observed in cores MRS-CS27 and MRS-CS18 were analysed for elemental composition by Itrax $\mu$-XRF core scanner and for gamma density and MS by Geotek MSCL (Figs. 2, 5 and 6; sections 3.1 and 3.2). Using these general geochemical and physical properties and their stratigraphic positions, these layers are correlated with the well-known tephra layers (i.e., Marmara tephra, MT-1 and MT-2), previously documented in detail and correlated to their sources (i.e., Cape Riva eruption of Santorini and the Campanian Ignimbrite, respectively) by Çağatay et al. (2015) (Figs. 2, 5 and 6; Table S1 and S2). In addition, the onset and termination ages of the main Holocene Marmara sapropel (MSAP-1) were used for core MRS-CS27 (Çağatay et al., 2015) (Table S2).

\subsubsection{Age-depth modelling}

The age-depth models of the studied cores were constructed using all the age data, explained in sections 3.6.1 to 3.6.3, listed in Tables S1 and S22 and plotted in Fig. S1 of the Supplementary Information (Figs. $4 \mathrm{a}$ and $\mathrm{b}$ ). For the construction the R-studio and the script 
"CLAM" (Blaauw, 2010) was used. The script creates non-Bayesian, cubic spline age-depth model, calculating the $\% 95$ Gaussian confidence interval around the best model.

\section{Results}

4.1 Lithology, paleontology, geochemistry and physical properties

The lithological and paleontological description of the studied cores, together with the TOC contents, are presented as lithological logs in Figs. 2 and 7, and their geochemistry is illustrated as element and element-ratio profiles in Figs. 5, 6 and 8. The detailed description and interpretations, based on the lithological, paleontological and geochemical data, are provided for each core below.

\subsubsection{Core MRS CS-27}

The core consists essentially of two marine units and an intervening lacustrine unit, based mainly on the fossil content (Fig. 2). The upper marine unit include a homogeneous olive gray clay (Munsell colour scale: 5Y5/2) from top to $0.45 \mathrm{mbsf}$ and olive grey to dark olive grey (5Y4/2, 5Y3/2) sapropel (Marmara Sapropel-1, MSAP-1) between 0.45 and 2.15 mbsf, which contains up to $5.8 \%$ TOC (Fig. 2). The MSAP-1 is commonly laminated with distinct laminations in its lower part from 1.85 to $2.15 \mathrm{mbsf}$, and shows some bioturbation in its upper $0.185 \mathrm{~m}$ and middle (0.80-1.09 mbsf) parts. The marine unit including the MSAP-1 contains benthic (mostly Bolivina sp., Bulumina and Brizalina sp.) and pelagic (mainly Globigerina sn.) foraminifera, echinoid spicules and juvenile bivalves. The MSAP-1 is also enriched in es and spore aggregates and rare plant remains. The sand $(>62 \mu \mathrm{m})$ fraction in the lower part of MSAP-1 contains some $0.5-1 \mathrm{~mm}$ euhedral, secondary gypsum crystals.

The marine unit is characterized by relatively low gamma density $\left(<1.5 \mathrm{~g} / \mathrm{cm}^{3}\right)$ and magnetic susceptibility (MS $<50 \mathrm{SI}$ ) and high $\mu$-XRF Br counts (up to $230 \mathrm{cps}$ ), especially in the MSAP-1 interval. The upper part of the marine unit including the upper part of MSAP-1 is also characterized by relatively high Br-TOC ratio $(>60)$, whereas the lower part of MSAP-1 is lower in Br-TOC ratio than the upper marine and lower lacustrine units (Fig. 5). The MSAP-1 shows an upward decreasing gamma density and low magnetic susceptibility compared to the rest of the upper marine unit (Fig. 5).

The latest lake/marine transition occurs from $2.65 \mathrm{mbsf}$ to $2.15 \mathrm{mbsf}$, and is characterized by a high $\mu$-XRF Ca, with another smaller Ca peak at 2.95 mbsf (Fig. 5). This 
interval is a grey (Gley1 5/10Y) mud with black Fe-monosulphide spots, and contains a rich population of bivalve shells and shell fragments. The bivalve population consists of a mixture of juvenile marine and brackish-freshwater bivalves (e.g. Turritella sp., Turricaspia sp., Dreissena sp.). The sand fraction of the lower part of interval contains faecal pellets, 1-2 mmsize pyrite concretions and euhedral to subhedral secondary gypsum crystals.

The lacustrine unit below the latest lake/marine transition is $15.03 \mathrm{~m}$-thick homogeneous grey (5Y5/1 to 5Y54/1) mud (Fig. 2). The upper part of this unit between 2.65 and $4.05 \mathrm{mbsf}$ is enriched in Fe-monosulphide (FeS) spots between and small $(1-3 \mathrm{~mm})$ white bivalve (mostly Dreissena rostriformis) shell fragments. The FeS-rich upper part of the unit, as well as the carbonate-rich transitional interval, is high in MS (up to $450 \mathrm{SI}$ ) and downward increasing gamma density. The lacustrine unit contains up to $10 \mathrm{~mm}$-thick laminae and beds of shell debris (fragments) at 2.98, 10.825, 12.168, 12.273, 13.013, 13.088 and 13.173 mbsf. Some levels contain up to $20 \mathrm{~mm}$ thick silt lenses (e.g., 13.86-13.89, 14.14-14.17, 14.25-14.28, 15.78$15.88 \mathrm{mbsf}$ ). The interval from 14.20 to $15.80 \mathrm{mbsf}$ is homogeneous olive grey mud (gley1 4/10Y) with high $\mu$-XRF Ca counts (up to $7000 \mathrm{cps}$ ) and relatively high TOC contents (up to $2.1 \mathrm{wt} \%$ ) (Figs. 2 and 5). Below this carbonate- and TOC-rich layers, small correlative peaks of $\mathrm{Ca}$ and TOC occur until a $3 \mathrm{~cm}$-thick, well sorted, medium to fine grade sand layer with an erosional basal contact at 18.83 mbsf above a marine unit. The lacustrine unit contains $\mu \mathrm{XRF}$ Ca peaks at 2.85 mbsf, 4.40, 4.75, 5.00, 5.10, 5.35, 5.75, 6.40, 9.45, 11.90, 12.70, 13.85, 14.25, 14.85, a large peak between 15.75 and $15.90 \mathrm{mbsf}$, at $16.75 \mathrm{mbsf}, 17.0 \mathrm{mbsf}$ and $17.50 \mathrm{mbsf}$. Some of these Ca peaks (e.g., 12.70, 14.25, $14.85 \mathrm{mbsf}$ ) correspond to shell-rich (mostly Dreissena rostriformis) horizons and are characterised by high $\mathrm{Sr}-\mathrm{Ca}$ ratio (Fig. 5). Most $\mathrm{Ca}$ peaks, including the large Ca peak in the 15.75-15.90 mbsf interval and in the lake/marine transition zone (2.65 mbsf to $2.15 \mathrm{mbsf}$ ), are low in $\mathrm{Sr}$ and $\mathrm{Sr}-\mathrm{Ca}$ ratio. The $\mathrm{Br}$ content and $\mathrm{Br}$ TOC ratio of the lacustrine unit are low compared with the upper part of latest marine unit, with some relatively high and fluctuating values of Br-TOC ratio in 2.25-5.50 mbsf and 12.7-14.0 mbsf intevals (Figs. 6 and 8a).

The lacustrine unit contains two distinct tephra layers (Marmara Tephra, MT-1 and MT2) at 6.955-7.005 mbsf and 13.835-13.88 mbsf intervals, each $\sim 50 \mathrm{~mm}$ in thickness. A cryptotephra (MT-3) is present at 16.18 mbsf, which consists of dispersed fine-sand-size glass shards and plagioclase crystals in a $2 \mathrm{~mm}$ - thick layer. It has high MS values ( $\sim 360$ IS) and high Ca ( $\sim 3000 \mathrm{cps}$ ), with no particular enrichment in $\mu$-XRF $\mathrm{K}$ and $\mathrm{Zr}$. The presence of abundant plagioclase and relatively high $\mathrm{Ca}$ in this tephra suggests its calc-alkaline affinity. 
MT-1 is brownish gray (10YR6/1 to $10 \mathrm{YR} 4 / 2)$ with some dark laminae and a sharp basal boundary, and shows normal size grading. It is low in $\operatorname{Zr}(\sim 400 \mathrm{cps})$ and $\mathrm{K}$, and characterized by low gamma density $\left(1.5 \mathrm{~g} / \mathrm{cm}^{3}\right)$ and a high MS (450 SI) (Fig. 5). MT-2 is grey (5Y6/1) with sand size glass shards. It is enriched in $\mu$-XRF K (1400 cps) and $\operatorname{Zr}$ (750 cps), and has a relatively high gamma density $\left(1.8 \mathrm{~g} / \mathrm{cm}^{3}\right)$ and low to moderate MS ( 350 SI) (Fig. 5). Considering their stratigraphic position, AMS radiocarbon ages, geochemical composition and MSCL physical properties, we correlate MT-1 and MT-2 with the tephra layers that were previously documented in the SoM cores, and correlated by Çağatay et al. (2015) with the Cape Riva eruption of Santorini and Campanian Ignimbrite (CI). The Santorini Cape Riva eruption (MT-1) and the CI (MT-2) are dated at 21.98 $\pm 0.88 \mathrm{ka} \mathrm{BP}$ (Pichler and Friedrich, 1976) and $39.28 \pm 0.11$ ka (DeVito et al., 2001; Pyle et al., 2006), respectively. The crypto tephra MT-3 is not characterized by any distinct element anomalies, such as $\mathrm{K}$ and $\mathrm{Zr}$, and is not so far correlated with its volcanic source.

Between 17.68 and $17.83 \mathrm{mbsf}$, the basal part of the lacustrine mud unit is a $15 \mathrm{~cm}$ thick, normally graded, fine sand to coarse silt layer (Fig. 2). This basal layer contains mm-size Dreissena sp. shell fragments and has a sharp erosional basal boundary. The second marine unit below includes two sapropels, MSAP-2 and MSAP-3, with an intervening $0.47 \mathrm{~m}$ thick lacustrine unit between 19.60 and 20.07 mbsf.

The MSAP-2 is $1.59 \mathrm{~m}$ thick, distinctly laminated, olive grey, very dark green to very dark greyish brown (5Y4/2, Gley1 3/10Y, 10YR 3/2) mud with up to $5.5 \mathrm{wt} \%$ TOC. The upper part of the MSAP-2 contains echinoid spicules, juvenile marine bivalve and $<1 \mathrm{~mm}$ size pyrite concretions. MSAP-2 has a relatively low gamma density $\left(<1.4 \mathrm{~g} / \mathrm{cm}^{3}\right)$, low MS $(<50 \mathrm{SI})$ and high $\mu$-XRF Br (up to $170 \mathrm{cps}$ ), low Br-TOC ratio (<40) and high S-Ti ratio (Figs. 5 and 8a). It also shows high $\mu$-XRF Ca counts (up to $700 \mathrm{cps}$ ) in its lower part between 18.9 and 19.45 mbsf. The lacustrine unit between MSAP-2 and MSAP-3 is grey (5Y4/1), locally laminated mud with FeS spots, Dreissena sp. shell fragments and mm-size secondary euhedral gypsum crystals. This unit contains a $45 \mathrm{~mm}$-thick, graded sand to silt bed and is characterized by relatively low (0.5-2 wt\%) TOC values, high Sr-Ca ratio, moderate $\mu$-XRF Zr ( 200 cps), locally high $\mu$-XRF Mn and local $\mu$-XRF Ca peaks in its upper part (Fig. 5). The MSAP-3 between $20.07 \mathrm{mbsf}$ to the base of the core is a dark olive grey laminated mud representing part of a sapropel unit. It contains up to $3.9 \mathrm{wt} \%$ TOC and is devoid of any macro- and micro-fossils. The sand fraction of the MSAP-3 contains abundant euhedral mm-scale secondary gypsum 
crystals. It is relatively higher in $\mathrm{K}$ and $\mathrm{Br}$ than the MSAP-2 and MSAP-1 and has high S-Ti ratio (Fig. 5).

\subsubsection{Core MRS CS-18}

The core consists mainly of two lacustrine units separated by a marine unit (Fig. 2). The uppermost lacustrine unit is a $3.65 \mathrm{~m}$ thick homogeneous greenish grey, grey, to dark grey (5Y5/1 to 5Y54/1, gley 14/10Y) mud, containing fresh/brackish water bivalve (mainly Dreissena rostriformis) shells and shell fragments, which are relatively abundant at $0.175,0.30$, $0.50,0.71,0.745,0.98,1.12-1.155,1.56,1.643-1.68,1.79-1.83,1.935,2.015-2.19,3.06-3.64$ mbsf (Fig. 2). There is a fine sand of $1 \mathrm{~cm}$ thickness between 3.64-365 mbsf with sharp upper and erosional lower contacts. The lacustrine unit contains two 1-2 mm-thick iron monosulphide (FeS) laminae at 1.20 and $1.85 \mathrm{mbsf}$ and $\mathrm{FeS}$ spots at 120-124, 1.405-1.44, 2.533-2.61, and 2.85 mbsf, which display high MS values between 1.20 and $3.0 \mathrm{mbsf}$. It is faintly laminated dark grey mud (gley $14 / 10 \mathrm{Y}$ ) between 2.35 and $3.05 \mathrm{mbsf}$ and has a high density $\left(>1.7 \mathrm{~g} / \mathrm{cm}^{3}\right)$ in its lower part between 2.70-3.64 mbsf (Fig. 6). This lacustrine unit is characterized by lower TOC (mostly $<1$ wt \%), lower $\mathrm{Br}(<150 \mathrm{cps})$ and higher Br-TOC ratio $(>90)$ than those in the underlying marine unit (Figs. 6 and 8b).

An $80 \mathrm{~mm}$-thick brown ash layer is observed between 2.13 and $2.21 \mathrm{mbsf}$. It is characterized by high MS, high $\mu$-XRF K (1050 cps) and Zr ( 600 cps) counts and relatively low gamma density. With its geochemical and physical properties and stratigraphic position, it is similar to tephra layer MT-2 in core MRS-CS27, and is therefore correlated with the CI having an age 39.28 \pm 0.11 cal ka (DeVito et al., 2001; Pyle et al., 2006) (Figs. 2, 5 and 6). A dark grey silty mud layer between 3.07 and $3.09 \mathrm{~cm}$ displays high $\mathrm{Ca}$-Ti ratio $(\sim 35)$ and low Fe-Mn ratio ( 30) (Fig. 6). A faintly grey, $2 \mathrm{~mm}$ thick layer centred at $309.5 \mathrm{cmbsf}$ is a crypto tephra with the presence of fine to very fine sand size glass fragments and plagioclase crystals. This tephra layer is characterized by a relatively high MS ( 300 IS), high density $\left(\sim 1.8 \mathrm{~g} / \mathrm{cm}^{3}\right)$ and low Sr-Ca ratio, and correlated with MT-3 observed in core MRS-CS27, based on its stratigraphic position and physical-chemical properties (Fig. 2).

The marine unit below the upper lacustrine unit is $4.05 \mathrm{~m}$ thick between 3.65 and 7.70 mbsf, interrupted by a 0.23 m-thick brackish lacustrine interval between 4.37 and 4.60 (Fig. 2). The marine unit includes three sapropel layers, MSAP-2, MSAP-3 and MSAP-4, with TOC contents ranging from 2 to $4.9 \mathrm{wt} \%$ (Fig. 2). The upper sapropel unit, MSAP-2 between 3.65 and 4.37 mbsf, is an olive grey laminated sapropel (MSAP-2) with TOC contents of up to 3.7 
wt $\%$ and low density and MS values (Figs. 2 and 6). There is a lack of micro and macro fossils in this unit, except for a translucent juvenile marine bivalve at $4.15 \mathrm{mbsf}$ and a few echinoid spicules. The sand fraction in MSAP-2 contains abundant well developed secondary gypsum crystals and pyritized faecal pellets. The lacustrine interval between MSAP-2 and MSAP-3 consists of a homogeneous dark greenish grey mud with less than $1.30 \mathrm{wt} \%$ TOC. It contains abundant Dreissena sp. shell fragments, ostracoda, rare gastropods (Turricasipa sp., one reworked Turritella sp. shell) (Fig. 7), faecal pellets, <1-mm size pyrite nodules, and some secondary euhedral gypsum crystals. This lacustrine unit in core MRSCS18 is correlated with the similar lacustrine unit in cores MRS CS27 in the same stratigraphic position (Fig. 2).

The sapropel layer MSAP-3 between 4.60 to $5.78 \mathrm{mbsf}$ is a greenish grey to olive grey finely laminated mud containing up to $3.67 \mathrm{wt} \%$ TOC (Fig. 2). It has sharp upper and lower boundaries, marked with the occurrence of sand beds, with erosional bottom contacts. The sand at the base of MSAP-3 is 6-7 cm-thick, a dark green graded medium-grained sand layer, enriched in benthic foraminifera and shell fragments, whereas the one at the upper boundary is $1 \mathrm{~cm}$-thick fine-grained sand. The MSAP-3 is devoid of any foraminifera, but contains abundant spores, rare echinoid, sponge spicules and Turritella sp. and some 1-2 mm euhedral gypsum crystals (Fig. 7). The interval between MSAP-3 and MSAP4 (5.80 and $6.30 \mathrm{mbsf}$ ) is a homogeneous, dark greenish grey mud, with relatively low (1.44-2.5 wt \%) TOC values. This marine interval contains a very rich and diverse population of benthic foraminifera including Bolivina sp., Bulumina sp., Brizalina sp., Cassudilina sp., Elphidium sp., Nonion sp., Uvigerina sp. and Textularia sp. (Fig. 7). It also includes marine bivalves and pelagic foraminifera (mainly Globotrancana sp.), and is locally enriched in secondary euhedral gypsum crystals. The MSAP4 between 6.30 and $7.01 \mathrm{mbsf}$ contains the highest TOC contents with up to $4.9 \mathrm{wt} \%$. It is greenish grey to olive grey mud that is faintly laminated in the upper part and distinctly laminated in the lower part. The upper faintly laminated part is devoid of foraminifera and bivalve fauna, whereas the middle distinctly laminated part from 6.55 to 6.85 mbsf includes a diverse benthic foraminiferal fauna, some pelagic foraminifera (mainly Globigerina sp.) (Fig. 7), and abundant secondary gypsum crystals. The lowest part of the sapropel from 6.85 to 7.01 mbsf is characterized by a very scarce marine fauna. The marine unit between 7.01 and 7.70 is a dark green grey to green grey sapropelic mud with TOC contents of $1.4-2.3 \mathrm{wt} \%$. This part contains sparse fossil content consisting of mainly Elphidium sp. and Brizalina sp, Echinoid spicules and ostracods, with some pyritized faecal pellets and euhedral secondary gypsum crystals (Fig. 7). 
The marine unit displays a relatively high $\mu$-XRF $\mathrm{Br}$ counts (up to $185 \mathrm{cps}$ ), especially in the sapropel layers, with Br and S profiles paralleling that of the TOC (Fig. 6). The highest TOC interval MSAP-4 is characterized by the highest $\mu$-XRF $\mathrm{Br}$ and $\mathrm{S}$ counts and high $\mu$-XRF $\mathrm{Ca}$ and $\mathrm{Sr}$ counts (both $\sim 7000 \mathrm{cps}$ ) and high Sr-Ca ratio, and low but upward increasing $\mathrm{Br}$ TOC ratio (Figs. 2, 6 and 8b). The MSAP-2 and MSAP-3 layers show and upward decreasing Br-TOC ratio. The low TOC interval of the marine unit between 5.65 and 6.15 mbsf has low $\mathrm{Br}(\sim 65-125 \mathrm{cps})$, and displays relatively high $\mu$-XRF $\mathrm{Ca}$ and $\mathrm{K}$ counts (600 cps) and low $\mathrm{Br}-$ TOC ratio. The sapropel layers have a relatively low gamma density and MS, except for the low TOC part of MSAP-3 which is relatively high in gamma density.

The unit from $7.70 \mathrm{mbsf}$ down to the base of the core at $14.05 \mathrm{mbsf}$ is homogeneous greenish grey lacustrine mud which contains less than $1.2 \mathrm{wt} \%$ TOC (Fig. 2). The unit commonly contains scattered bivalve (mostly Dresissena rostriformis) shells and shell fragments, ostracoda and pyritized faecal pellets and boring-infills. Some cm-thick intervals (e.g., 9.61, 10.70 and $12.25 \mathrm{mbsf}$ ) are enriched in white sand-size Dreissena sp. shell fragments, which commonly correspond to positive Ca excursions (Fig. 6). The interval including the lake/marine transition between 7.87-7.40 mbsf is also characterized by relatively high Ca counts (up to $3700 \mathrm{cps}$ ), Mn (up to $\sim 500 \mathrm{cps}$ ) and a sharp S peak with up to $205 \mathrm{cps}$. The upper part of the lacustrine unit and the transition zone have high magnetic susceptibility, which corresponds to the dark grey to black FeS spots and bands. At 13.27-13.38 m interval, an unidentified cryptotephra characterized by high $\mathrm{K}$ counts (up to $850 \mathrm{cps}$ ) is observed. This crypto tephra with sparse volcanic glass shards in about an $11 \mathrm{~cm}$-thick sediment layer has a slightly higher density $\left(2.0 \mathrm{~g} / \mathrm{cm}^{3}\right)$ than the surrounding background sediments, with no MS expression only slight enrichment in Zr. The layer also contains partially sericitized feldspars, polycrystalline and microcrystalline quartz grains.

\subsection{Chronology}

The constructed age-depth model of the cores (Fig.s $4 \mathrm{a}$ and b), are in good agreement with the independently dated regional terrestrial records, such as those from the Lake Ohrid (Fig. 1a), located along the same latitudinal zone and affected by continental and Mediterranean climatic conditions. The TOC data sets of the studied cores MRS-CS18 and MRS-CS27, plotted with the NGRIP time scale, and the Lake Ohrid TOC data set, which is age-calibrated by tephrochronology (11 tephra layers) and by cross-correlation of geochemical proxy data with orbital parameters (Francke et al., 2016) show excellent correlation (Fig. 3), suggesting the robustness of the age models for the studied cores (see also section 5.3 and Fig. 8 therein). 


\subsubsection{Chronology of Core MRS-CS27}

According to the age-depth model, the basal part of core MRS-CS27 reaches $94.52 \pm 1.35$ $\mathrm{ka} \mathrm{BP}$, and the core includes a hiatus between 68.58 and $74.01 \mathrm{ka}$ BP (Fig. 4a). This hiatus is represented by $15 \mathrm{~cm}$-thick thick normally graded sand layer with an erosional basal boundary (Fig. 2). It is characterized by a sharp change in the density, magnetic susceptibility and geochemical parameters such as TOC (Fig. 5). The hiatus corresponds to the distinct reflection surface in high resolution seismic profiles (Fig. 1c), which is labelled as the "Red" surface by Sorlien et al. (2012) and Grall et al. (2013). It is characterized by a distinct negative polarity in the synthetic seismograms because of the sharp density contrast between the lacustrine sediment above and the sapropel below (Kende et al., in review). The lacustrine unit between the MSAP-2 and MSAP-3 has an age spanning between $92.32 \pm 0.88$ and 86.60 $\pm 3.17 \mathrm{ka}$ BP. The cryptotephra MT-3 (16.18 cmbsf) with a presently unidentified source, is dated at 57.02 $\pm 2.90 \mathrm{ka} \mathrm{BP}$. The sedimentation rate for the late MIS5 (94.5-74 ka BP; $140 \mathrm{~mm} / \mathrm{kyr}$ ) is higher than that for MIS4-MIS3 (110 mm/kyr but much lower than that for MIS2 (620 mm/kyr).

\subsubsection{Chronology of core MRS-CS18}

The age-depth model of core MRS-CS18 shows that of the core section extends from 26.4 to $173.1 \mathrm{ka} \mathrm{BP}$, with two hiatuses at 3.65 and $5.78 \mathrm{mbsf}$ (Fig. 4b). The upper hiatus is represented by $1 \mathrm{~cm}$-thick fine sand with a sharp erosional boundary, and characterized by a sharp change in density, MS, TOC, Br and $\mathrm{Zr}$ (Fig. 6). It is $\sim 9$ ka-long hiatus spanning from $79.28 \pm 1.00$ to $70.08 \pm 0.96 \mathrm{ka}$ BP during which the record of GI 19, GI 20 and later part of GI 21 is missing (Figs. 3a, c, f). As in core MRS-CS27, this hiatus is located between the lacustrine sediment above and the sapropel below, and matches the distinct reflecting surface in the seismic profile in Fig. 1D and the "Red" reflecting surface of Sorlien et al. (2012) and Grall et al. (2013). The lower hiatus at $5.78 \mathrm{mbsf}$ is represented by the 5-6 cm-thick normally graded sand layer, and corresponds to a sharp change in density, MS, TOC, Br and $\mathrm{K}$. The hiatus corresponds to $\sim 5 \mathrm{ka}$ long gap from $108.20 \pm 0.97$ to $103.36 \pm 0.91 \mathrm{ka} \mathrm{BP}$, which covers the period of GI 24 (Figs. 3a, b, e). The $1 \mathrm{~cm}$-thick very fine sand, marking the upper boundary of MSAP-3 at $4.60 \mathrm{cmbsf}$ ( $\sim 92 \mathrm{ka} \mathrm{BP}$ ), does not represent a significant hiatus according to the correlation with the NGRIP oxygen isotope data and the age-depth model (Figs. 3 and 4).

The crypto-tephra MT-3 at $309.5 \mathrm{cmbsf}$ in core MRS-CS18 is dated at $57.77 \pm 1.00 \mathrm{ka}$ $\mathrm{BP}$, and the lake/marine transition of the SoM during the penultimate glacial/interglacial transition (i.e. MIS6/MIS5 transition) took place at $\sim 134.06 \pm 1.10 \mathrm{ka}$ BP. The sapropel units 
MSAP-2, MSAP-3 and MSAP-4 with TOC contents greater than $2 \mathrm{wt} \%$ were deposited during $87.16 \pm 0.98$ - 79.28 $\pm 1.00 \mathrm{ka} \mathrm{BP}$ (hiatus), 103.36 \pm 0.91 (hiatus) - $91.95 \pm 0.74 \mathrm{ka}$ BP and $131.17 \pm 1.02-112.25 \pm 1.37 \mathrm{ka} \mathrm{BP}$, with an intervening relatively low TOC (2-2.5 wt\%) interval between MSAP-4 and MSAP-3 during 112.25 - 108.20 ka BP. The lacustrine interval with relatively low TOC values ( $<2 \mathrm{wt} \%$ ) is dated between 79.28 (hiatus) $-87.16 \mathrm{ka} \mathrm{BP}$, and the potassium-rich tephra near the base of the core at $160.61 \pm 0.79$.

The sedimentation rate for MIS5 and MIS6 in core MRS-CS18 are $90 \mathrm{~mm} / \mathrm{kyr}$ and 145 $\mathrm{mm} / \mathrm{kyr}$, respectively (Fig. 4b). A sharp change in sedimentation rate occurs at $\sim 40 \mathrm{ka} \mathrm{BP}$, with the rate increasing from $45 \mathrm{~mm} / \mathrm{kyr}$ between $71 \mathrm{ka}$ and $40 \mathrm{ka} \mathrm{BP}$ to $170 \mathrm{~mm} / \mathrm{kyr}$ between 40 and $27 \mathrm{ka} \mathrm{BP}$. A decrease in the sedimentation rate is observed for the period between $\sim 160$ and $\sim 166 \mathrm{k}$ BP near the bottom of the core.

\subsubsection{Correlation of cores MRS-CS18 and MRS-CS27 with cores MRS-CS22 and MD04-2745}

Using the lithology and fossil content, the stratigraphic units in lower part of cores MRSCS18 and MRS-CS27 of the İmralı Basin can be correlated with those in core MRS-CS22 from the Western High studied by Kende et al. (in review) (Fig. 2) and the units in the latter core can be dated using the age-depth model of core MRS-CS18. The lowest foraminifera-rich part of core MRS-CS22 below 19.3 mbsf is correlated with a lithologically and paleontologically similar marine unit of MIS5d age in core MRS-CS18 (Figs. 2 and 7). Hence core MRS-CS22 in its lower part includes a sedimentary section covering the periods of MIS5d to MIS5a ( 116 - $70 \mathrm{ka} \mathrm{BP}$ ). The overlying unit between 18.3 and 19.3 in core MRS-CS22 is a sapropel with TOC contents of up to $3 \mathrm{wt} \%$ and can be matched with sapropel MSAP-3 of MIS5c age in İmrali cores (Fig. 2). The interval between 16.8 and $18.3 \mathrm{mbsf}$ is low in TOC and is tentatively correlated with the lacustrine unit corresponding to MIS5b in the Imralı cores, although the lacustrine nature of the unit in core MRS-CS22 has not yet been established (Kende et al. in review). This presumably brackish unit is overlain by a sapropel unit between 15.5 and 16.8 mbsf according to its TOC content ( $>2 \mathrm{wt} \%$ ). This sapropel is correlated with the MSAP-3 in the İmralı cores. Finally, the interval between $\sim 14.0-15.5 \mathrm{mbsf}$ in core MRS-CS22 below the hiatus is deposited under brackish conditions, based on the absence of alkenones (Kende et al., in review). However, this unit is likely to have been deposited during marine connection of the SoM, with a strong Black Sea outflow forming a brackish surface water.

The stratigraphy of MIS5 in core MD04-2745 recovered from -98 on the northern shelf edge in the SoM (for location see Fig. 1b) (Çağatay et al., 2009) and İmrali cores MRS-CS18 
and MRS-CS27 can be correlated, with the presence the two sapropel layers, MSAP-2 (MIS5a) and MSAP-3 (MIS5c), and the intervening lacustrine unit (MIS5b), in all the cores. The unit below MSAP-3 with 1-1.5 \% TOC in core MD04-2745 likely represents MIS5d, observed in the İmrali cores.

\section{Discussion}

5.1 Timing of the Aegean and Black Sea connections and hydrological changes during MIS5 and MIS6

The paleontological data, together with the age model for studied cores and MRS-CS27, shows that the SoM was connected with the Aegean Sea for most part of the MIS5, except between $\sim 93.9-87.2 \mathrm{ka}$ (in core MRS-CS18) or between 92.4-86.6 ka BP (in core MRS-CS27), during which the connection was disrupted for 6-7 ka. This lacustrine unit deposited in this interval corresponds to the stadial MIS5b, which spans from 92 to $87 \mathrm{ka} \mathrm{BP}$ according to Martrat et al. (2004). This age interval is therefore in agreement with our model age for this stratigraphic interval in the studied cores. The SoM was disconnected also between 173 and $134 \mathrm{ka} \mathrm{BP}$, which includes the MIS6. The marine connection of the SoM during the Termination II (MIS6/MIS5 transition) took place at $134.0 \pm 2.1 \mathrm{ka} \mathrm{BP}$, according to our age model of core MRS-CS18 (Fig. 4).

The timings of these events in the SoM are in general agreement with the U/Th-dated speleothem oxygen isotope data from Sofular near the SW Black Sea coast in NW Anatolia, which shows relatively high $\delta^{18} \mathrm{O}$ values over the periods of marine connections (i.e., during MIS5 interstadials e, c, and a) and low values during the marine disconnections (i.e, MIS5 stadials $b$ and $d$ ) of the Black Sea, resulting mainly from the source-water effect (Baderstcher et al., 2011). The only disparity between environmental conditions in the SoM and Black Sea is found for MIS5d, during which marine conditions in the former basin and lacustrine conditions in the latter prevailed. This implies that the sea level remained below the Bosporus sill at that time to prevent the passage of marine waters to the Black Sea "lake". This conclusion is supported by the sea level curve of Grant et al. (2012) (Fig. 8d), which shows a sea-level below $-40 \mathrm{~m}$ (the present sill depth of Bosporus) during the main part of MIS5d.

Based on paleontological evidence, however, different depositional conditions have been suggested for the Black Sea during MIS5. For example, Zubakov (1988) shows marine 
conditions during MIS5 interstadials c and e, while Svitoch et al. (2000) determined marine conditions only during MIS5a. For MIS6, Zubakov (1988) shows the existence of lacustrine conditions in the Black Sea, whereas Svitoch et al. (2000) suggests marine conditions during 170-150 ka BP (MIS6). Svitoch's (2000) findings are in disagreement with our data from the SoM as well as with the Sofular speleothem data from SW Black Sea coast in NW Anatolia (Baderstcher et al., 2011), which show no marine connection neither for the SoM nor for the Black Sea at that time.

Considering the global sea level curve of Grant et al. (2012) (Fig. 8d), the marine connection of the SoM at $\sim 134 \mathrm{ka} \mathrm{BP}$ and the disconnection during MIS5b would occur if the sill depth of the Dardanelles Strait was below -80 m (i.e., lower than the present sill depth of $-65 \mathrm{~m}$ ) during Termination II. A similar sill depth of $-84 \mathrm{~m}$ for the Dardanelles Strait existed during Termination I, as testified by the widespread existence of paleoshorelines of the Marmara "Lake" in the form of berms and wave-cut notches, which are dated at 12.5 cal ka BP (Çağatay et al., 2003, 2009; Polonia et al., 2004; Eriş et al., 2011). This implies that the Dardanelles Strait's sill depth during the glacial periods was deeper than that during the interglacial periods, probably due to fluvial down-cutting under a relatively low base level; the isostatic effect of increased water column on the strait's channel after the marine reconnection is estimated to be negligible because of limited width of the strait (Smith et al., 1995).

The Sr-Ca and U-Ca ratios of ostracod shells (Wegwerth et al., 2014) and marine dynocysts distribution (Shumilovskikh et al., 2013b) indicate that marine reconnection of the Black Sea occurred at $128.1 \pm 0.7 \mathrm{ka}$ BP, during Termination II (Fig. 8e). The timing of this marine reconnection is $\sim 6 \mathrm{ka}$ later than marine reconnection of the SoM at $\sim 134.0 \pm 2.13 \mathrm{ka} \mathrm{BP}$. During Termination I (MIS2/MIS1 transition) the initial marine reconnection of the SoM started at 14.7 cal ${ }^{14} \mathrm{C}$ kyr BP (Vidal et al., 2010) and the full connection with the appearance of Mediterranean euryhaline fauna occurred at $12.56 \mathrm{ka}$ BP (Çağatay et al., 2015). This was followed by the initial marine reconnection of the Black Sea at $9.4 \mathrm{cal}{ }^{14} \mathrm{C}$ kyr BP (Major et al., 2006; Ryan et al., 2007; Bahr et al., 2008) or 9 cal ${ }^{14} \mathrm{C}$ ka BP (Soulet et al., 2011), and the colonization of the sea with the Mediterranean marine fauna around $7.5 \mathrm{cal}{ }^{14} \mathrm{C}$ kyr BP (Ryan et al., 1999). Hence, time lag between the marine connections of the Black Sea and SoM during Termination I $\sim^{5} \mathrm{ka}$, which is similar to the time lag during the Termination II. As discussed by Wegwerth et al. (2014), the timing of connections of the Black Sea during Terminations I and II are compatible with the present sill depth of the Bosporus at -35 to- $40 \mathrm{~m}$. 
The MIS5 period with its sapropels is characterized by a low sedimentation rate of $\sim 10.5$ $\mathrm{mm} / \mathrm{kyr}$, which is similar to the sedimentation rate for MIS4, but lower than that for MIS2, MIS3 and MIS6. Despite the warm and high precipitation conditions during MIS5, the relatively low sedimentation rate can be explained by the dense vegetation cover resulting in low erosion rates in the catchment area and the high sea levels causing the landward migration of the coastline and increase in relative distance of the core site from the sediment source (river mouths on the southern coastline). Accordingly, the detrital input varied in conformity with stadial and interstadial oscillations within the MIS5, as indicated by variations in the K profile (Fig. 6). For example, high detrital mineral input, in the form of illite clay, occurs during the period of 111.5-108 ka BP (stadial MIS5d), whereas this input decreases during 128.5-112.9 ka BP (mainly interstadial MIS5e) and Termination II (Fig. 6), which can be explained by changes in precipitation, vegetation density and sea level, as explained above. High K counts also occurs during 150-135 ka BP, which is likely due to low lake levels during the stadial period, when the coastline and river mouths migrated closer the core site.

However, high K counts in the Black Sea record were previously interpreted as evidence of glacier melt-water inputs from the European ice sheets arriving in the Black Sea mainly from the Caspian Sea via the Manych-Kerch Strait (Wegwerth et al., 2014). Wegwerth et al. (2014) detected two such melt water pulses in the Black Sea during Termination II (130.6-131.55 and 132.55-133.7 ka BP) by high $\mathrm{K} / \mathrm{Al}$ of the bulk sediments and the very low $\mathrm{Sr} / \mathrm{Ca}$ of ostracod shells. Other melt-water pulses in the Black Sea during various global warming (interstadial) events have been also documented (Mangerud, et al., 2004; Chepalyga, 2007; Bahr et al., 2007; Baderstcher et al., 2011; Wegwerth et al., 2014). For example, Baderstcher et al. (2011) correlated negative $\delta^{18} \mathrm{O}$ values of -13 to -17.5 per mil in the Sofular speleothem in NW Anatolia, with melt water inputs in the Black Sea during 16.5-14.5, 135, and 175-180 ka BP; the first two correspond to transitions before the Terminations I and II. Evidence of similar warming events, with positive excursions of $\mathrm{Ca}, \mathrm{MS}$, density, and $\mathrm{K}$, are also present in in the SoM records during MIS5 and MIS6 (Figs. 6 and 7), suggesting high detrital input. However, the source of the detrital input cannot be unequivocally attributed to the Black Sea outflow events in the SoM using the presently available proxy data.

\subsection{Marine Isotope Stage 5 sapropels}

Three sapropel units (MSAP-4, MSAP-3 and MSAP-2) with TOC values greater than 2 $\mathrm{wt} \%$ were deposited during MIS5, which correspond mainly to the interstadial sub-stages e, c, 
and a (Fig. 2). However, the upper part of MSAP-2 is missing in both studied cores due to the hiatuses. The formation of this hiatus can be explained by sliding and slumping of sediments over the weak substrate of the sapropel during a period of low sea level (e.g., Kopf et al., 2007), which would be especially the case in core MRS-CS18, with its location on a slope and with its hiatus representing a longer time span than that in core MRS-CS27 (Fig. 1d).

Sapropel layers are well defined by $\mu$-XRF Br, mirroring the TOC profiles with similar positive excursions (Figs. 5 and 6). This indicate the strong association between $\mathrm{Br}$ and the marine organic matter, as has been documented in previous studies (Mayer et al., 1981, 2007; Ziegler et al., 2008). Sapropel layers in the SoM are characterized by relatively low Br/TOC values compared to the lacustrine sediments of MIS -2 to MIS-4, except for the upper part of MSAP-1 and the uppermost marine unit in core MRS-CS27 (Fig. 6). In MSAP-3 and MSAP2 , there is a relative upward decrease in $\mathrm{Br} / \mathrm{TOC}$ values, suggesting an increasing contribution of terrestrial organic matter with decreasing age, whereas a reverse (upward increasing) trend is observed for MSAP-4 (MIS5e)(Fig. 6). The Br/TOC profile shows high values for the lacustrine period from $\sim 70 \mathrm{ka} \mathrm{BP}$ (end of hiatus) to $26.40 \mathrm{ka} \mathrm{BP}$ (core top) in core MRS-CS18, with a very high peak at $53.2 \mathrm{ka} \mathrm{BP}$ (Fig. 6). The much higher ratio during the lacustrine MIS4MIS3 than that for the lacustrine MIS6 is due to the relatively higher $\mathrm{Br}$ and lower TOC vales, during the former period (Fig. 6). The high Br values during MIS4-MIS3 sediments are in turn likely due to algal organic matter production under brackish water conditions, because the freshening of the SoM was slow, with partial continuation of marine conditions after the MIS5, as suggested by the oxygen isotope analysis (Çağatay et al., 2009) and modelling studies, based on pore-water analysis (Aloisi et al., 2015). On the other hand, low $\mathrm{Br}$ (average: $100 \mathrm{cps}$ ) and relatively high TOC values (0.4-1.5\%), with low Br/TOC values $(<50)$, during MIS6 imply relatively high terrestrial organic matter input under fresh water conditions (Fig. 5).

The high S enrichment just below the lacustrine/marine transition, prior to each sapropel deposition in the SoM is similar to the one observed immediately below the Mediterranean sapropels (Passier et al., 1996); this enrichment results from the formation of pyrite by reaction of the downward diffusing $\mathrm{HS}^{-}$from the marine sediments with the upward diffusing $\mathrm{Fe}^{2+}$ from the underlying lacustrine sediments.

The first marine species such as benthic foraminifera (Elphidium sp., Brizalina sp.) and Echinoid spines appear after the marine reconnection at 134 ka BP (Fig. 7). Sapropel MSAP-4 of Eemian age with TOC contents of $2-4.9 \mathrm{wt} \%$ started depositing at $\sim 131 \mathrm{ka} \mathrm{BP}$, about $\sim 3$ 
ka after the marine reconnection, considering a lower cut off limit of $2 \%$ TOC for the sapropel. Low diversity of benthic foraminifera and absence of pelagic foraminifera indicate low salinity conditions during the period from 134 to $128.6 \mathrm{ka} \mathrm{BP}$ including the period from the marine reconnection and the early part of MSAP-4 deposition. Part of MSAP-4 deposited between 128.4 and $122.9 \mathrm{ka}$ BP has a diverse population of benthic foraminifera, characteristic of suboxic conditions, and pelagic foraminifera (mainly Globigerina sp.), which together with relatively high Mn contents, indicate increased sea surface salinities and the suboxic bottom water conditions (Figs. 6 and 7). This in agreement with the dinoflagellate cyst data from the Black Sea, which show that high sea-surface salinity of $\sim 28-30$ psu is already established there around the same time, during the Eemian (Shumilovskikh et al., 2013a). The upper part of MSAP-4 is devoid of benthic and pelagic fauna strongly suggesting low salinity surface waters and bottom water anoxia during 123-112 ka BP (Fig. 7). The anoxic bottom water conditions are supported by low $\mu$-XRF Mn counts observed in this interval (Fig. 6).

The period from 112 to to the hiatus at $108 \mathrm{ka} \mathrm{BP}$, corresponding to a part of stadial MIS5d (MIS5d: 115-105 ka BP, Martrat et al., 2004) (Fig. 8j), is characterized by relatively low TOC, high diversity of benthic foraminifera, abundance of pelagic (mainly Globigerina sp.) foraminifera, and relatively high $\mu$-XRF Mn counts (Figs. 6 and 7). These attributes indicate low organic matter preservation under relatively oxic bottom waters and reasonably high surface salinities, comparable to the present-day conditions in the SoM. The MSAP-3 and MSAP-2 are characterized by rare Echinoid spines, sponge spicules and juvenile marine bivalves, and the near absence of benthic and pelagic foraminifera, suggesting low surface salinity and bottom water dysoxic/anoxic conditions (Fig. 7). The deposition of these two sapropels, MSAP3 and MSAP2, are separated by a period of lacustrine conditions during 93 - 87 ka BP (i.e., stadial MIS5b), as indicated by the presence of fresh/brackish water bivalve fauna, implying sea level below the sill depth of the Dardanelles Strait (Fig. 8d).

Although, the sapropels in the SoM, Black Sea and Mediterranean Sea are related to the same climatic events of global warming and sea level rise, the causal mechanisms and timings of their deposition in these basins were different. The sapropel deposition in the SoM (and the Black Sea) appears to have been triggered by marine flooding events, the timing of which is determined by the rate of sea level rise and the sill depth of the connecting shallow straits of Bosporus and Dardanelles at the time (Çağatay et al., 2009, 2015). The marine flooding of the fresh-brackish basins of the SoM and Black Sea would cause a density stratification of the water column, decreased renewal of deep waters and increased organic matter preservation, all 
leading to the sapropel formation (Çağatay et al., 2009, 2015). On the other hand, the sapropel formation in the Mediterranean is believed to have been controlled by sea level rise and precession minima, with the former causing preconditioning and prevention of deep water formation, and the latter enhanced monsoon intensity and runoff from North Africa, resulting in density stratification and stagnation (see Rohling et al., 2015 for discussion). The Mediterranean sapropels S3, S4 and S5 were formed during interstadial periods of MIS-5 (a, c, and e), whereas sapropel S6 was deposited during 180-170 ka BP within the glacial MIS6 (Grant et al., 2012). Thus, MSAP2, MSAP-3 and MSAP-4 sapropels of the SoM are broadly the time equivalent of S3, S4 and S5 sapropels in the Mediterranean, but the equivalent of Mediterranean S6 sapropel should be absent in the SoM and the Black Sea, based on the considerations of the global sea level curve (Grant et al., 2012) (Fig. 8d) and the Sofular speleothem oxygen isotope data (Baderstcher et al, 2011) (Fig. 8f).

Although sapropels were deposited in the same interstadial sub-stages of the MIS5 and during MIS1 in the SoM, Black Sea and Mediterranean Sea, the timing of their formation was different in these basins. The onset of MIS5 sapropels, MSAP-2 and MSAP-4, in the SoM is dated at 86.6 , and $131.2 \mathrm{ka} \mathrm{BP}$, while that of MSAP-3 could not only be constrained between 108.2 and 103.3 ka BP, because of its disconformable basal boundary. The sapropels S3, S4 and S5 in the Mediterranean Sea started forming at $\sim 85 \mathrm{ka} \mathrm{BP}, \sim 107 \mathrm{ka}$ and $\sim 128 \mathrm{ka}$ BP, respectively (Grant et al., 2012), and the MIS5e (Eemian) sapropel in the Black Sea at $127.6 \mathrm{ka}$ BP (Wegwerth et al., 2014). Therefore, the onset ages of formation of the two SoM MIS5 sapropels are in general 1-3 ka older than the corresponding Mediterranean sapropels of MIS5. Similarly, the Holocene MSAP-1 sapropel started forming at 12.33 \pm 0.35 (Çağatay et al., 2015), nearly $1.5 \mathrm{ka}$ earlier than the Mediterranean S1 sapropel (10.8 cal yr BP; De Lange et al., 2008), $\sim 4$ ka earlier than the onset of the formation of the Holocene Black Sea sapropel, dated at $\sim 8$ cal yr BP (Jones and Gagnon, 1994; Bahr et al., 2005, 2006; Lamy et al., 2006). The formation of sapropels in the SoM being earlier than those in the Mediterranean sapropels does not necessarily indicate a causal link between the Black Sea outflow and the sapropel formation in the Eastern Mediterranean, as claimed by some earlier studies (Olausson, 1991; Aksu et al., 1995). They suggest that substantial fresh water outflows from glacial Black "Lake" after each marine reconnection was the trigger for sapropel formation in the Eastern Mediterranean. However, this hypothesis is now mainly discarded especially for the sapropel S1 formation, because it was demonstrated that the sea surface salinity was up to 6 psu higher-than-present in the SoM during the deposition of S1 and that the salinity gradients indicated a southern 
Mediterranean source fresh water in the Levantine Basin (Sperling et al., 2003; Vidal et al., 2010). Instead, the differences in timing of the sapropel deposition in the silled SoM and Black Sea marginal basins, relative to those of the quasi-equivalent Mediterranean sapropel, are likely related to timing of establishment of the suboxic/anoxic bottom water conditions, which would in turn be controlled by the sill depth of the connecting shallow straits, rate of primary productivity, the rate and extent of sea level rise, and the size and depth of the basins. The shallow sill depths of straits would delay the marine connections, but would result in establishment of early anoxic conditions, thereby shortening the time lag between the marine connection and the onset of sapropel deposition in the marginal silled basins. Similarly, high sea levels with a rapid rise, as in the case of MIS5e would result in early connections, but cause a delay in the sapropel formation because of the relatively effective bottom water circulation in small basins such as the SoM. This would explain the difference in the time lapse between the marine connection and the formation of sapropels during MIS5e (MSAP-4) and Holocene (MSAP-1), which is $\sim 3 \mathrm{ka}$ (this study) and $\sim 0.3 \mathrm{ka}$ (Çağatay et al., 2015), respectively.

\subsection{Comparison with the global and regional records and paleoclimatic implications}

As already explained in section 3.4.2, the $\mu$-XRF Ca data, related to the endogenic carbonate production in the epilimnion of the Marmara "lake", show good correlation with the NGRIP oxygen isotope data (NGRIP, 2005), with the increase (decrease) in Ca corresponding to Greenland interstadials (stadials) (Figs. 3, 9a, d). There is also a very close correlation between the TOC data of the SoM with the continental records from Lake Ohrid in Macedonia/Albania in the Balkans (i.e., TOC data of Francke et al., 2016 and pollen data of Sinopoli et al., 2018) (Figs. 8f, i, j). The SoM and Lake Ohrid are located $\sim 500 \mathrm{~km}$ apart along similar latitudes and are presently both affected by continental and Mediterranean climatic conditions. The TOC data of SoM and TOC and pollen data of Lake Ohrid show conformable sharp changes during the stadial and interstadial periods of MIS5, with high organic productivity and preservation during the interstadial periods in both basins. The SoM data also show excellent correlation with the global sea level curve (Fig. 8d) and oxygen isotope ratio of pelagic foraminiferal data from the SE Aegean Sea (Grant et al., 2012) (Fig. 8d), surface temperature (SST) data from core ODP977 (Martrat et al., 2007) (Fig. 8j), and benthic and planktonic oxygen isotope data from the Western Mediterranean (Sanchez-Goni et al., 1999, 2005; 2012; not plotted), as well as with the pollen and TOC data of the Black Sea for MIS5e that show warm and high precipitation conditions during 126.4-122.9 ka BP in north Anatolia (Shumilovskikh et al., 2013b; Wegwerth et al., 2014) (Fig. 8e). 
The close correlation of the marine and continental records from the western and central Mediterranean regions including the SoM, Aegean Sea, Black Sea, southern Europe, and Anatolia with the Greenland interstadials and stadial events shown by the NGRIP oxygen isotope record (Svensson et al., 2006, 2008; Rasmussen et al., 2006; Wolff et al., 2010) indicates the common strong influence of the North Atlantic climatic events in the region, triggered by the changes in the Atlantic Meridional Overturning Circulation (AMOC) (Ganopolski and Rahmstorf, 2001; Drysdale et al., 2007; Sinopoli et al., 2018). The geochemical proxy-records, such as the $\mathrm{Ca}$ and TOC excursions suggest that the amplitude of the millennial and multimillennial climate oscillations in the SoM during the MIS6 (Saalian or Penultimate Glacial Period) was much less than those during MIS4-MIS2 (Last Glacial Period).

\subsection{Age of the "Red" seismic reflecting surface}

From the chronology of cores located in different parts of the SoM, it is clear that the "Red" or "H1" seismic reflecting surface with a high amplitude and a negative polarity (Sorlien et al., 2012; Grall et al., 2013) corresponds to a hiatus developed during the sea level lowering at the MIS5/MIS4 transition. Hence, the age of the prominent seismic reflecting surface is considerably different from the age of $110 \mathrm{ka} \mathrm{BP}$, estimated by Sorlien et al. (2012) on the basis of extrapolated sedimentation rates (see Kende et al, in review, for further discussion). Sorlien et al. (2012) and Grall et al. (2013) used the ages of the "Red" reflecting surface and other surfaces to estimate the fault slip rates and the age of mass transport deposits in the SoM.

The hiatus (and Red seismic reflecting surface) is most likely related to mass-wasting events during the sea-level lowering at the MIS5/MIS4 transition. However, its duration appears to be distinct in different locations in the SoM; in cores MRS-CS18, MRS-CS27 and MRSCS22, the hiatus corresponds to time intervals of 79.3-70.1 ka BP, 74.0 - 68.6 ka BP and 72$70 \mathrm{ka} \mathrm{BP}$, respectively. The length of hiatus interval appears to be related to the site of the core location, with the sites on relatively steep slopes (e.g., core MRS-CS18, Fig. 2d) having a relatively long gap in the stratigraphy, because of causal processes of the mass-wasting and/or non-deposition.

\subsection{Possible sources of the new cryptotephra}

The two unidentified tephra (MT-3 and MT-4), with model ages of $57.02 \pm 2.90 \mathrm{ka}$ BP

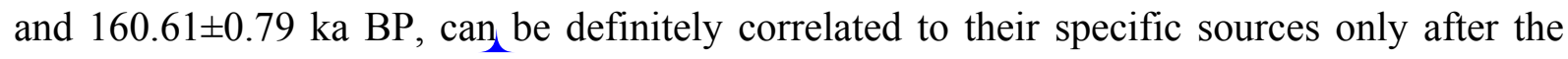
detailed electron probe micro analysis (EPMA), which is presently underway. However, based on the general chemical composition and model-age, some preliminary evaluation can be made 
about their possible source regions. The MT-3, with plagioclase- and Ca-rich and incompatibleelement (K, Zr)-poor composition, has calc-alkaline characteristics, and hence, likely originated from the Aegean volcanic arc province (Druitt et al., 1999; Hardiman, 1999; Bachmann et al., 2010).

Considering its potassium-rich composition, stratigraphic position and model age, several candidate regions can be proposed for the source of MT-4, such as the Vico volcano in Lazio region of Italy (Bear et al., 2009), the southern Aegean Sea (Smith et al., 1996; Bachmann et al., 2010), the Cappadocia volcanic province in Central Anatolia (Druitt et al., 1995; Aydar and Gourgaud, 1998; Kuzucuoğlu et al., 1998; Siebel et al., 2011), and the Eastern Anatolian volcanic province (Pierce et al., 1990; Özdemir et al., 2006; Sumita, M., Schmincke, 2013a,b).

The potassium-rich alkaline "Ignimbrite B" (Vico B) eruption of Vico occurred at $157 \pm 3$ ka (Laurenzi and Villa, 1987), and its record is dated in Lake Ohrid at $162 \pm 6 \mathrm{ka}$ BP (Leicher et al., 2016). Plinian eruptions of high-silica rhyolitic compositions occurred from Kos-Nisyros volcanic complex and the Acıgöl volcanic complex of Cappadocia in Central Anatolia around the same time, with the former eruption dated at 161 $\pm 2 \mathrm{ka} \mathrm{BP}$ (Bachmann et al., 2010) and the latter (the Upper Acigöl Tuff) 163 \pm 7 ka BP (Schmitt et al., 2011). A major potassium-rich eruption of similar age ( $160 \pm 13 \mathrm{ka} \mathrm{BP})$ occurred from the Nemrut volcano in Eastern Anatolia depositing the potassium-rich Ahlat Pumice (AP-2) unit (Sumita and Schmincke, 2013a). Considering its $11-\mathrm{cm}$ thickness, together with the close age interval of these eruptions, the cryptotephra MT-4 may represent a composite record of most, if not all, of these eruptions. Considering the easterly wind trajectories, however, the Eastern Anatolia appears to be less likely source than the others.

\section{Conclusions}

Multy-proxy records of two cores MRS-CS18 and MRS-CS27 from the SoM provide significant paleo-environmental and hydrographic records for MIS5 and MIS6, reaching back to $173 \mathrm{ka} \mathrm{BP}$. These records show that the marine reconnection of the SoM during Termination II (MIS6/MIS5 transition) occurred at $\sim 134.06 \pm 1.10 \mathrm{ka} \mathrm{BP}$ and that three sapropels (MSAP-4, MSAP-3 and MSAP-2) were deposited during the three MIS5 interstadials, e, c and a. During stadial MIS5b ( 92.7-87.2 ka), the marine connection was disrupted when sea level dropped below the sill depth of the Dardanelles Strait, whereas marine conditions, with relatively low TOC contents $(<2 \%)$ prevailed during the stadial MIS5d. 
Sapropel MSAP-4 of Eemian age started forming at $\sim 131 \mathrm{ka} \mathrm{BP,} \mathrm{about} \sim 3 \mathrm{ka}$ after the marine reconnection. Low salinity and oxic to suboxic bottom conditions prevailed during the period from 134 to 128.4 ka including the period from the marine reconnection to the early part of MSAP-4 deposition. During 128.4 and 122.9 ka BP MSAP-4 deposition continued under relatively high salinity and suboxic bottom water conditions, whereas the low sea surface salinities and anoxia prevailed during 122.9- 112.3 ka BP. Relatively high sea surface salinity water existed and the sapropel formation was disrupted from $112 \mathrm{ka} \mathrm{BP}$ to 103-108 ka BP (part of stadial MIS5d) because of the increased bottom water circulation, similar to present-day conditions. The MSAP-3 and MSAP-2 were deposited under low surface salinity and dysoxic/anoxic bottom water conditions.

The marine conditions during MIS5d and disconnection during MIS5b suggests that a threshold sill depth of -50 to $-60 \mathrm{~m}$ for the Dardanelles Strait during most of MIS5, which is 5-15 m higher than the present sill depth of -65. However, the sill depth must have been lower (at least at $\sim-75 \mathrm{~m}$ ) during the reconnection at Termination II. A disruption in the marine connection of the Black Sea during MIS5b (as well as its marine reconnection at $\sim 128 \mathrm{ka} \mathrm{BP}$ ) is in agreement with a sill depth of $\sim-35$ to $-40 \mathrm{~m}$ for the Bosporus Strait, a depth similar to that of the present day.

The SoM geochemical proxy records correlate well with the regional terrestrial and marine records and the NGRIP oxygen isotope record with its glacial and interglacial (GI) phases, showing the important common effect of the North Atlantic climatic events triggered by the perturbations in the Atlantic Meridional Overturning Circulation (AMOC). The sedimentary records of the studied cores also indicate the presence of two distinct and two crypto tephra layers. The distinct tephra layers, MT-1 and MT-2, are previously known from the SoM, which are correlated with the Cape Riva eruption of Santorini Volcano (22 cal kyr BP) and the Campanian Ignimbrite (39.3 ka BP), respectively. The newly discovered but unidentified cryptotephra layers, MT-3 and MT-4, were dated at 57.02 $\pm 2.90 \mathrm{ka}$ BP and $160.61 \pm 0.79 \mathrm{ka} \mathrm{BP}$, respectively. The former is of calc-alkaline affinity and whereas the latter is of potassium-rich alkaline affinity. Detailed EPMA analyses are underway to match the crypto-tephra MT-3 and MT-4 with their sources.

The regional "Red" seismic reflecting surface in the SoM corresponds to a hiatus that developed during the sea-level lowering at the MIS5/MIS4 transition, as result of removal the 
sediments by mass wasting processes. This hiatus represents different gaps in the stratigraphy in different parts of the SoM.

\section{Acknowledgements}

The authors would like to thank the scientific team of Marsite cruise, and in particular the cochiefs, Louis Geli and Livio Ruffine, and the captains and crews of RV Pourquoi pas? The Marsite cruise was co-funded by the EC FP7 project MARSITE (grant number: 308417) "Longterm monitoring experiment in geologically active regions of Europe prone to natural hazards:the Supersite concept" under the call ENV.2012.6.4-2 and by the "Laboratoire d'Excellence" LabexMER (ANR-10-LABX-19) through the projects called MicroGaMa and MISS Marmara, and by a grant from the French government under the program "Investissements d'Avenir". 


\section{References}

Aksu, A. E., Yaşar, D., \& Mudie, P. J., 1995. Paleoclimatic and paleoceanographic conditions leading to development of sapropel layer S1 in the Aegean Sea. Palaeogeography, Palaeoclimatology, Palaeoecology, 116 (1-2), 71-101.

Aksu, A. E., Hiscott, R. N., \& Yaşar, D., 1999. Oscillating Quaternary water levels of the Marmara Sea and vigorous outflow into the Aegean Sea from the Marmara Sea-Black Sea drainage corridor. Marine Geology, 153(1-4), 275-302.

Aksu, A. E., Hiscott, R. N., Kaminski, M. A., Mudie, P. J., Gillespie, H., Abrajano, T., \& Yaşar, D., 2002. Last glacial-Holocene paleoceanography of the Black Sea and Marmara Sea: stable isotopic, foraminiferal and coccolith evidence. Marine Geology, 190(1-2), 119-149.

Algan, O., Çağatay, N., Tchepalyga, A., Ongan, D., Eastoe, C., \& Gökaşan, E., 2001. Stratigraphy of the sediment infill in Bosphorus Strait: water exchange between the Black and Mediterranean Seas during the last glacial Holocene. Geo-Marine Letters, 20(4), 209-218.

Aloisi, G., Soulet, G., Henry, P., Wallmann, K., Sauvestre, R., Vallet-Coulomb, C., \& Bard, E., 2015. Freshening of the Marmara Sea prior to its post-glacial reconnection to the Mediterranean Sea. Earth and Planetary Science Letters, 413, 176-185.

Angino, E.E., Billings, G.K., Andersen, N., 1966. Observed variations in the strontium concentration of sea water Chemical Geology, 1: 145-153. https://doi.org/10.1016/0009$\underline{2541(66) 90013-1 .}$.

Aydar, E., Gourgaud, A, 1998. The geology of Mount Hasan stratovolcano, central Anatolia, Turkey. J Volcanol. Geotherm Res., 85(1-4):129-152

Aydoğdu, A., Pinardi, N., Özsoy, E., Danabasoglu, G., Gürses, Ö., Karspeck, A., 2018. Circulation of the Turkish Straits System under interannual atmospheric forcing. Ocean Science, 14: 999-1019, doi:10.5194/os-14-999-2018.

Bachmann, O., Schoene, B., Schnyder, C., Spikings, R., 2010. The 40Ar/39Ar and U/Pb dating of young rhyolites in the Kos-Nisyros volcanic complex, Eastern Aegean Arc, Greece: Age discordance due to excess 40Ar in biotite. Geochem. Geophys. Geosyst. 11. https://doi.org/10.1029/2010GC003073. 
Badertscher, S., Fleitmann1, D., Cheng, H., Edwards, R.L., Göktürk, O.M., Zumbühl, A., Leuenberger, M., Tüysüz, O., 2011. Pleistocene water intrusions from the Mediterranean and Caspian seas into the Black Sea. Nature Geoscience http://dx.doi.org/10.1038/ngeo1106.

Bahr, A., Lamy, F., Arz, H., Kuhlmann, H.,Wefer, G., 2005. Late glacial to Holocene climate and sedimentation history in the NW Black Sea. Marine Geology 214, 309-322.

Bahr, A., Arz, H., Lamy, F., Wefer, G., 2006. Late glacial to Holocene paleoenvironmental evolution of the Black Sea, reconstructed with stable oxygen isotope records obtained on ostracod shells. Earth and Planetary Science Letters 241, 863-875.

Bahr, A., Lamy, F., Arz, H.W., Major, C.O., Kwiecien, O.,Wefer, G., 2007. Abrupt changes of temperature and water chemistry in the late Pleistocene and early Holocene Black Sea. Geochemistry, Geophysics, Geosystems 9, Q01004. http://dx.doi.org/10.1029/2007GC001683.

Bahr, A., Lamy, F., Arz, H. W., Major, C., Kwiecien, O., \& Wefer, G., 2008. Abrupt changes of temperature and water chemistry in the late Pleistocene and early Holocene Black Sea. Geochemistry, Geophysics, Geosystems, 9(1).

Barker, S., G. Knorr, R. L. Edwards, F. Parrenin, A. E. Putnam, L. C. Skinner, E. Wolff and M. Ziegler., 2011. 800,000 years of abrupt climate variability. Table S2: Synthetic Greenland record.

Bear, A. N., Giordano, G., Giampaolo, C., \& Cas, R. A. F., 2009. Volcanological constraints on the post-emplacement zeolitisation of ignimbrites and geoarchaeological implications for Etruscan tomb construction (6th-3rd century BC) in the Tufo Rosso a Scorie Nere, Vico Caldera, Central Italy. Journal of Volcanology and Geothermal Research, 183(3-4), 183-200.

Berner, R.A., 1985. Sulfate reduction, organic matter decomposition, and pyrite formation. Phil. Trans. R. Soc. London 48, 25-38.

Beşiktepe, Ş.T., Sur, H.I., Özsoy, E., Latif, M.A., O $\square$ uz, T., Ünlüata, Ü., 1994. The circulation and hydrography of the Marmara Sea. Progress in Oceanography 34 (4), 285-334.

Blaauw, M., 2010. Methods and code for 'classical' age-modelling of radiocarbon sequences. Quaternary Geochronology 5: 512-518.

Çağatay, M. N., Görür, N., Algan, O., Eastoe, C., Tchapalyga, A., Ongan, D., \& Kuşcu, I. 2000. Late Glacial-Holocene palaeoceanography of the Sea of Marmara: timing of connections with the Mediterranean and the Black Seas. Marine Geology, 167 (3-4), 191-206. 
Çağatay, M. N., Görür, N., Polonia, A., Demirbăg, E., Sakınç, M., Cormier, M. H.,\& Eriş, K., 2003. Sea-level changes and depositional environments in the Izmit Gulf, eastern Marmara Sea, during the late glacial-Holocene period. Marine Geology, 202(3-4), 159-173.

Çağatay, M. N., Eriş, K., Ryan, W. B. F., Sancar, Ü., Polonia, A., Akçer, S., \& Bard, E., 2009. Late Pleistocene-Holocene evolution of the northern shelf of the Sea of Marmara. Marine Geology, 265 (3-4), 87-100.

Çağatay, M. N., Öğretmen, N., Damcı, E., Stockhecke, M., Sancar, Ü., Eriş, K. K., \& Özeren, S., 2014. Lake level and climate records of the last $90 \mathrm{ka}$ from the Northern Basin of Lake Van, eastern Turkey. Quaternary Science Reviews, 104, 97-116.

Çağatay, M. N., Wulf, S., Sancar, Ü., Özmaral, A., Vidal, L., Henry, P., \& Gasperini, L., 2015. The tephra record from the Sea of Marmara for the last ca. $70 \mathrm{ka}$ and its palaeoceanographic implications. Marine Geology, 361, 96-110.

Calvert, S.E., Pedersen, T.F., 1993. Geochemistry of Recent oxic and anoxic marine sediments: Implications for the geological record. Marine Geology, 113, 67-88.

Chepalyga, A.L., 2007. The late glacial great flood in the Ponto-Caspian Basin. In: YankoHombach, V., Gilbert, A.S., Dolukhanov, P.M. (Eds.), The Black Sea Flood Question. Springer, The Netherlands, pp. 119-148.

Chiggiato, J.; Jarosz, E.; Book, J. W.; Dykes, J.; Torrisi, L.; Poulain, P.-M.; Gerin, R.; Horstmann, J.; Beşiktepe, Ş., 2012. Dynamics of the circulation in the Sea of Marmara: numerical modeling experiments and observations from the Turkish straits system experiment, Ocean Dynam. 62 (1), 139-159. https://doi.org/10.1007/s10236-011-0485-5

Cohen, A.S., 2003. Paleolimnology, The History and evolution of Lake Systems. Oxford University Press. 500p.

Croudace, W., Rindby, A., Rothwell, R.G., 2006. ITRAX: description and evaluation of a new multi-function X-ray core scanner. In: Rothwell, R.G. (Ed.), New Techniques in Sediment Core Analysis. Geological Society, London Special, Publication vol. 267, pp. 51-63.

Cullen, H. M., deMenocal, P. B., Hemming, S., Hemming, G., Brown, F. H., Guilderson, T., \& Sirocko, F., 2000. Climate change and the collapse of the Akkadian empire: Evidence from the deep sea. Geology, 28(4), 379-382. 
De Lange, G.J., Thomson, J., Reitz, A., Slomp, C.P., Speranza Principato, M., Erba, E., Corselli, C., 2008. Synchronous basin-wide formation and redox-controlled preservation of a Mediterranean sapropel. Nat. Geosci. 1, 606-610.

De Vivo, B., Rolandi, G., Gans, P.B., Calvert, A., Bohrson, W.A., Spera, F.J., and Belkin, H.E., 2001. New constraints on the pyroclastic eruptive history of the Campanian volcanic Plain (Italy), Mineral. Petrol., 73, 47-65.

Deniz, A., Toros, H., Incecik, S., 2011. Spatial variations of climate indices in Turkey. Int. J. Climatol.31, 394-403.

Druitt, T.H., Brenchley, P.J., Gokten, Y.E., Francaviglia, V., 1995. Late Quaternary rhyolitic eruptions from the Acigol complex, Central Turkey. J. Geol. Soc., 152:655-667.

Druitt, T.H., Edwards, L., Mellors, R.M., Pyle, D.M., Sparks, R.S.J., Lanphere, M., Davies, M., Barriero, B., 1999. Santorini Volcano. Geological Society, London. Memoir 19, 165 p.

Drysdale, R.N., Zanchetta, G., Hellstrom, J.C., Fallick, A.E., McDonald, J., Cartwright, I., 2007. Stalagmite evidence for the precise timing of North Atlantic cold events during the early last glacial. Geology, 35: 77-80.

EIE., 1993. Sediment data and sediment transport amounts for surface waters in Turkish rivers. General Directorate of State Electric Services, EIE, Ankara, Rep 93-59.

Eriş, K. K., Ryan, W. B. F., Çağatay, M. N., Sancar, U., Lericolais, G., Menot, G., \& Bard, E., 2007. The timing and evolution of the post-glacial transgression across the Sea of Marmara shelf south of Istanbul. Marine Geology, 243(1-4), 57-76.

Eriş, K. K., Çağatay, M. N., Akçer, S., Gasperini, L., \& Mart, Y., 2011. Late glacial to Holocene sea-level changes in the Sea of Marmara: new evidence from high-resolution seismics and core studies. Geo-Marine Letters, 31(1), 1-18.

Francke, A., Wagner, B., Just, J., Leicher, N., Gromig, R., Baumgarten, H. \& Leng, M. J., 2016. Sedimentological processes and environmental variability at Lake Ohrid (Macedonia, Albania) between $637 \mathrm{ka}$ and the present.

Ganopolski, A., Rahmstorf, S., 2001. Simulation of rapid glacial climate changes in a coupled climate model. Nature, 409: 153-158. 
Gökaşan, E., Ergin, M., Özyalvaç, M., Sur, H.I., Tur, H., Görüm, T., Ustaömer, T., Batuk, F.G., Alp, H., Birkan, H., Türket, A., Gezgin, E., Özturan, M., 2008. Factors controlling the morphological evolution of the Çanakkale Strait. Geo-Marine Letters 28, 107-129.

Gökaşan, E., Tur, T., Ergin, M., Görüm, T., Batuk, F.G., Sağc1, N., Ustaömer, T., Emem, O., Alp, H., 2010. Late Quaternary evolution of the Çanakkale Strait region (Dardanelles, NW Turkey): implications of a major erosional event for the postglacial Mediterranean- Marmara Sea connection. Geo-Marine Letters 30, 113-131.

Göktürk, O.M., Fleitmann, D., Badertscher, S., Cheng, H., Edwards, R.L., Leuenberger, M., Fankhauser, A., Tüysüz, O., Kramers, J., 2011. Climate on the southern Black Sea coast during the Holocene: implications from the Sofular Cave record. Quaternary Sci Rev 30:2433-2445

Grall, C., Henry, P., Thomas, Y., Westbrook, G. K., Çağatay, M. N., Marsset, B., Géli, L., 2013. Slip rate estimation along the western segment of the Main Marmara Fault over the last 405490 ka by correlating mass transport deposits. Tectonics, 32(6), 1587-1601.

Grant, K.M., Rohling, E.J., Bar-Matthews, M., Ayalon, A., Medina-Elizalde, M., Ramsey, C., Bronk, C., Satow, C., Roberts, A.P., 2012. Rapid coupling between ice volume and polar temperature over the past 150,000 years. Nature, 491 (7426), 744-747.

Hiscott, R.N., Aksu, A.E., Yaşar, D., Kaminski, M.A., Mudie, P.J., Kostylev, V.E., MacDonald, J.C., İşler, F.I., Lord, A.R., 2002. Deltas south of the Bosphorus Strait record persistent Black Sea outflow to the Marmara Sea since $\sim 10$ ka. Marine Geology 190, 95-118.

Hiscott, R.N., Aksu, A.E., Mudie, P.J., Kaminski, M.A., Abrajano, T., Yaşar, D., Rochon, A., 2007. The Marmara Sea gateway since $\sim 16$ ky BP: non-catastrophic causes of paleoceanographic events in the Black Sea at 8.4 and 7.15 ky BP. In: Yanko- Hombach, V., Gilbert, A.S., Dolukhanov, P.M. (Eds.), The Black Sea Flood Question. Springer, The Netherlands, pp. 89-117.

Ichikuni, M., Musha, S., 1978. Partition of strontium between gypsum and solution. Chemical Geology, 21 (3-4), 359-363. https://doi.org/10.1016/0009-2541(78)90055-4

Jones, G. A., \& Gagnon, A. R., 1994. Radiocarbon chronology of Black Sea sediments. Deep Sea Research Part I: Oceanographic Research Papers, 41(3), 531-557. 
Kazancı N., Leroy S., İleri Ö., Emre O., Kibar, M. and Öncel, S., 2004. Late Holocene erosion in NW Anatolia from sediments of Lake Manyas, Lake Ulubat and the southern shelf of the Marmara Sea, Turkey. Catena 57: 277-308.

Kende J., Henry P., Çağatay M. N., Eriş K. K., Grall. C, Paillès C., Delanghe D., Licari L, Thouveny N., Devouard B., Rostek F., Tachikawa K., Garcia M., Borschneck D., Beaufort L., Margerel J.-P., Bard E. (in review). Paleo-environment variability in the Sea of Marmara Sea since the last interglacial. Marine Geology.

Kopf, A., Stegmann, S., Krastel, S., Förster, A., Strasser, M. \& Irving, M., 2007. Marine deepwater free-fall CPT measurements for landslide characterisation off Crete, Greece (Eastern Mediterranean Sea) Part 2: Initial data from the Western Cretan Sea. In Submarine Mass Movements and their consequences (pp. 199-208). Springer, Dordrecht.

Köprülü, K., Alpar, B., \& Vardar, D., 2016. Last Glacial-Holocene stratigraphic development at the Marmara Sea exit of the Bosphorus Strait, Turkey. Marine Geophysical Research, 37(1), 21-35.

Kuzucuoğlu, C., Pastre, J.F., Black, S., Ercan, T., Fontugne, M., Guillou, H., Hatte, C., Karabıyıkoğlu, M., Orth, P., Türkecan, A., 1998. Identification and dating of tephra layers from Quaternary sedimentary sequences of Inner Anatolia, Turkey. Journal of Volcanology and Geothermal Research, 85, 153-172.

Kwiecien, O., Arz, H. W., Lamy, F., Wulf, S., Bahr, A., Röhl, U., \& Haug, G. H., 2008. Estimated reservoir ages of the Black Sea since the last glacial. Radiocarbon, 50(1), 99-118.

Lamy, F., Arz, H.W., Bond, G.C., Bahr, A., Pätzold, J., 2006. Multicentennial-scale hydrological changes in the Black Sea and northern Red Sea during the Holocene and the Arctic/North Atlantic Oscillation. Paleoceanography 21, PA1008.

Laurenzi, M. A., \& Villa, I. M., 1987. 40Ar/39Ar chronostratigraphy of Vico ignimbrites. Periodico di mineralogia, 56 (2-3), 285-293.

Leicher, N., Zanchetta, G., Sulpizio, R., Giaccio, B., Wagner, B., Nomade, S., Francke, A., and Del Carlo, P., 2016. First tephrostratigraphic results of the DEEP site record from Lake Ohrid, Macedonia. Biogeosciences, 13, 20151-20178. doi:10.5194/bg-13-2151-2016. 
Leventhal, S.J., 1983. An interpretation of carbon and sulfur relationships in Black Sea sediments as indicators of environments of deposition. Geochim. Cosmochim. Acta, 47, 133137. https://doi.org/10.1016/0016-7037(83)90097-2

Lyons, T.W., 1997. Sulfur isotopic trends and pathways of iron sulfide formation in upper Holocene sediments of the anoxic Black Sea. Geochimica et Cosmochimica Acta, 61, 33673382.

Major, C. O., Goldstein, S. L., Ryan, W. B., Lericolais, G., Piotrowski, A. M., \& Hajdas, I., 2006. The co-evolution of Black Sea level and composition through the last deglaciation and its paleoclimatic significance. Quaternary Science Reviews, 25(17-18), 2031-2047.

Mangerud, J., Jakobsson, M., Alexanderson, H., Astakhov, V., Clarke, G. K., Henriksen, M., \& Murray, A., 2004. Ice-dammed lakes and rerouting of the drainage of northern Eurasia during the Last Glaciation. Quaternary Science Reviews, 23(11-13), 1313-1332.MarsiteCruise report, 2014. MarsiteCruise expedition. http://dx.doi.org/10.17600/14000500.

Martrat, B., Grimalt, J. O., Lopez-Martinez, C., Cacho, I., Sierro, F. J., Flores, J. A. \& Hodell, D. A., 2004. Abrupt temperature changes in the Western Mediterranean over the past 250,000 years. Science, 306 (5702), 1762-1765.

Martrat, B., Grimalt, J.O., Shackleton, N.J., de Abreu, L., Hutterli, M.A., Stocker, T.F., 2007. Four climate cycles of recurring deep and surface water destabilizations on the Iberian margin. Science 317, 502-507.

Mayer, L. M., Macko, S. A. Mook, W. H., Murray, S. M., 1981. The distribution of bromine on coastal sediments and its use as a source indicator for organic matter, Org. Geochem., 3: 3742, doi:10.1016/0146-6380 (81) 90011-5.

Mayer, L. M., Schick, L. L. Allison, M. A. Ruttenberg, K. C., Bentley S. J., 2007. Marine vs. terrigenous matter in Louisiana coastal sediments: The uses of bromine: organic carbon ratios, Mar. Chem., 107, 244-254, doi:10.1016/j.marchem.2007.07.007.

McHugh, C. M., Gurung, D., Giosan, L., Ryan, W. B., Mart, Y., Sancar, U. \& Cagatay, M. N., 2008. The last reconnection of the Marmara Sea (Turkey) to the World Ocean: A paleoceanographic and paleoclimatic perspective. Marine Geology, 255(1-2), 64-82. 
Nowaczyk, N.R., Arz, H.W., Frank, U., Kind, J., Plessen, B., 2012. Dynamics of the Laschamp geomagnetic excursion from Black Sea sediments. Earth and Planetary Science Letters, 351$352,54-69$.

Olausson, E., 1991. Carbon and oxygen isotope composition of foraminifera in two cores from the Bannock Basin area, eastern Mediterranean. Marine geology, 100(1-4), 45-51.

Özdemir, Y., Karaoğlu, Ö., Tolluoğlu, A.Ü., Güleç, N., 2006. Volcanostratigraphy and petrogenesis of the Nemrut stratovolcano (East Anatolian High Plateau): the most recent postcollisional volcanism in Turkey. Chemical Geology 226, 189-211.

Özsoy, E., \& Ünlüata, Ü., 1997. Oceanography of the Black Sea: a review of some recent results. Earth-Science Reviews, 42(4), 231-272.

Palmer, M.R, Edmond, J.M., 1992. Controls over the strontium isotope composition of river water. Geochimica et Cosmochimica Acta, 56(5): 2099-2111. https://doi.org/10.1016/00167037(92)90332-D.

Passier, H.F., Middelburg, J.J., Van Os, B.J.H., De Lange, G.J., 1996. Diagenetic pyritisation under eastern Mediterranean sapropels caused by downward sulphide diffusion. Geochim. Cosmochim. Acta 60, 751-763.

Perini, G., Francalanci, L., Davidson, J.P., Conticelli, S., 2004. Evolution and Genesis of Magmas from Vico Volcano, Central Italy: Multiple Differentiation Pathways and Variable Parental Magmas. Journal of Petrology volume 45(1): 139-182 DOI: 10.1093/petrology/egg084

Pichler, H., Friedrich, W., 1976. Radiocarbon dates of Santorini volcanics. Nature 262, 373374.

Pearce, J.A., Bender, J.F., De Long, S.E., Kidd, W.S.F., Low, P.J., Güner, Y., Şaroğlu, F., Y1lmaz, Y., Moorbath, S., Mitchell, J.G., 1990. Genesis of collision volcanism in eastern Anatolia, Turkey. Journal of Volcanology and Geothermal Research 44, 189-229.

Polonia, A., Gasperini, L., Amorosi, A., Bonatti, E., Bortoluzzi, G., Cagatay, N. \& Seeber, L., 2004. Holocene slip rate of the North Anatolian Fault beneath the Sea of Marmara. Earth and Planetary Science Letters, 227(3-4), 411-426.

Pyle, D. M., Ricketts, G. D., Margari, V., van Andel, T., Sinitsyn, A. A., Praslov, N. D., and Lisitsyn, S., 2006. Wide dispersal and deposition of distal tephra during the Pleistocene 'Campanian Ignimbrite/Y5' eruption, Italy, Quaternary Sci. Rev., 25, 2713-2728. 
Rasmussen, S.O., Andersen, K.K., Svensson, A.M., Steffensen, J.P., Vinther, B.M., Clausen, H.B., Siggaard-Andersen, M.-L., Johnsen, S.J., Larsen, L.B., Dahl-Jensen, D., Bigler, M., Röthlisberger, R., Fischer, H., Goto-Azuma, K., Hansson, M.E., Ruth, U., 2006. A new Greenland ice core chronology for the last glacial termination. Journal of Geophysical Research 111, D06102. http://dx.doi.org/10.1029/2005JD006079.

Reimer, P.J., Bard, E., Bayliss, A., Beck, J.W., Blackwell, P.G., Bronk Ramsey, C., Buck, C.E., Cheng, H., Edwards, R.L., Friedrich, M., Grootes, P.M., Guilderson, T.P., Haflidason, H., Hajdas, I., Hatté, C., Heaton, T.J., Hoffmann, D.L., Hogg, A.G., Hughen, K.A., Kaiser, K.F., Kromer, B., Manning, S.W., Niu, M., Reimer, R.W., Richards, D.A., Scott, E.M., Southon, J.R., Staff, R.A., Turney, C.S.M., van der Plicht, J., 2013. IntCal13 and Marine13 radiocarbon age calibration curves, 0-50,000 years cal BP. Radiocarbon 55, 1869-1887.

Rohling, E. J., Marino, G., \& Grant, K. M., 2015. Mediterranean climate and oceanography, and the periodic development of anoxic events (sapropels). Earth-Science Reviews, 143, 6297.

Rosenthal,Y. Lear,C.H., Oppo, D.W., Linsley, B.K., 2006. Temperature and carbonate ion effects on $\mathrm{Mg} / \mathrm{Ca}$ and $\mathrm{Sr} / \mathrm{Ca}$ ratios in benthic foraminifera: Aragonitic species Hoeglundina elegans. Paleoceanography 21 (1), PA1007. 10.1029/2005PA001158.

Russell, A.D., Hönisch, B., Spero, H.J., Lea, D.W., 2004. Effects of seawater carbonate ion concentration and temperature on shell $\mathrm{U}, \mathrm{Mg}$, and $\mathrm{Sr}$ in cultured planktonic foraminifera. Geochimica et Cosmochimica Acta, 68(21): 4347-4361. doi:10.1016/j.gca.2004.03.013.

Ryan, W.B.F., Pitman III, W.C., Major, C.O., Shimkus, K., Moskalenko, V., Jones, J.A., Dimitrov, P., Görür, N., Sakınç, M., Yüce, H., 1997. An abrupt drowning of Black Sea shelf. Marine Geology 138, 119-126.

Ryan W, Pitman W., 1999. Noah's Flood: The New Scientific Discoveries About the Event that Changed History. New York: Simon \& Schuster. 319 pp.

Ryan, W.B., 2007. Status of the Black Sea flood hypothesis. The Black Sea Flood Question: Changes in Coastline, Climate, and Human Settlement. Springer, Dordrecht, pp. 63-88.

Sanchez-Goni, M.F., Bakker, P., Desprat, S., Carlson, A.E., Van Meerbeeck, C.J., Peyron, O., Naughton, F., Fletcher, W.J., Eynaud, F., Rossignol, L., Renssen, H., 2012. European climate optimum and enhanced Greenland melt during the Last Interglacial. Geology 40, 627e630. 
Sanchez-Goni, M.F., Eynaud, F., Turon, J.L., Shackleton, N.J., 1999. High resolution palynological record off the Iberian margin: direct land-sea correlation for the Last Interglacial complex. Earth Planet. Sci. Lett. 171, 123-137.

Sanchez-Goni, M.F., Loutre, M.F., Crucifix, M., Peyron, O., Santos, L., Duprat, J., Malaize, B., Turon, J.L., Peypouquet, J.P., 2005. Increasing vegetation and climate gradient in Western Europe over the Last Glacial Inception (122-110 ka): data model comparison. Earth Planet. Sci. Lett. 231, 111-130.

Schmitt, A.K., Danišík, M., Evans, N.J., Siebel, W., Kiemele, E., Aydin, F., Harvey, J.C., 2011. Acigöl rhyolite field, Central Anatolia (part 1): high-resolution dating of eruption episodes and zircon growth rates. Contrib. Mineral. Petrol., 162, 1215-1231. https://doi.org/10.1007.

Schöne, B.R., Zhanga, Z., Radermacher, P., Thébault, J., Jacob D.E., Nunn, E.V., Maurera AF., 2011. Sr/Ca and $\mathrm{Mg} / \mathrm{Ca}$ ratios of ontogenetically old, long-lived bivalve shells (Arctica islandica) and their function as paleotemperature proxies. Palaeogeography, Palaeoclimatology, Palaeoecology, 302 (1-2): 52-64. https://doi.org/10.1016/j.palaeo.2010.03.016

Shumilovskikh, L.S., Marret, F., Fleitmann, D., Arz, H.W., Nowaczyk, N., Behling, H., $2013 a$. Eemian and Holocene sea-surface conditions in the southern Black Sea: Organic-walled dinoflagellate cyst record from core 22-GC3. Mar. Micropaleon-tol.101, 146-160.

Shumilovskikh, L.S., Arz, H.W., Wegwerth, A., Fleitmann, D., Marret, F., Nowaczyk, N., Tarasov, P., Behling, H., 2013b. Vegetation and environmental changes in Northern Anatolia between 134 and 119 ka recorded in Black Sea sediments. Quaternary Research 80, 349-360.

Siani, G., Paterne, M., Arnold, M., Bard, E., Metivier, B., Tisnerat, N., Bassinot, F., 2000. Radiocarbon reservoir ages in the Mediterranean Sea and Black Sea. Radiocarbon 42, 271-280.

Siebel, W., Schmitt, A.K., Kiemele, E., Danišík, M, Aydin, F., 2011. Acigöl rhyolite field, central Anatolia (part II): geochemical and isotopic $(\mathrm{Sr}-\mathrm{Nd}-\mathrm{Pb}, \mathrm{d} 18 \mathrm{O})$ constraints on volcanism involving two high-silica rhyolite suites. Contrib Mineral Petrol., 162, 1233-1247. doi: 10.1007/s00410-011-0651-2.

Sinopoli, G., Masi, A., Regattieri, E., Wagner, B., Francke, A., Peyron, O., \& Sadori, L., 2018. Palynology of the Last Interglacial Complex at Lake Ohrid: palaeoenvironmental and palaeoclimatic inferences. Quaternary Science Reviews 180, 177-192. 
Smith, P.E., York, D., Chen, Y., Evensen, N.M., 1996. Single crystal 40Ar-39Ar dating of a Late Quaternary paroxysm on Kos, Greece: Concordance of terrestrial and marine ages. Geophys. Res. Lett., 23, 3047-3050. https://doi.org/10.1029/96GL02759.

Sumita, M., Schmincke, H.-U., 2013a. Impact of volcanism on the evolution of Lake Van II: temporal evolution of explosive volcanism of Nemrut Volcano (eastern Anatolia) during the past ca. 0.4 Ma. J. Volcanol. Geoth. Res. 253, 15-34.

Sumita, M., Schmincke, H.-U., 2013b. Impact of volcanism on the evolution of Lake Van I: evolution of explosive volcanism of Nemrut Volcano (eastern Anatolia) during the past $>400,000$ years. Bull. Volcanol. 75, 714-746. DOI: 10.1007/s00445-013-0714-5

Smith, A.D., Taymaz, T., Oktay, F., Yüce, H., Alpar, B., Başaran, H., Jackson, J.A., Kara, S., Şimşek, M., 1995. High resolution seismic reflection profiling in the Sea of Marmara (northwest Turkey): late Quaternary sedimentation and sea-level changes. Bulletin of the Geological Society of America 107, 923-936.

Sorlien, C. C., Akhun, S. D., Seeber, L., Steckler, M. S., Shillington, D. J., Kurt, H., \& İmren, C., 2012. Uniform basin growth over the last 500 ka, North Anatolian Fault, Marmara Sea, Turkey. Tectonophysics 518, 1-16.

Soulet, G., Ménot, G., Lericolais, G., Bard, E., 2011. A revised calendar age for the last reconnection of the Black Sea to the global ocean. Quaternary Science Reviews 30, 1019-1026.

Sperling, M., Schmiedl, G., Hemleben, Ch., Emeis, K.C., Erlenkeuser, H., Grootes, P.M., 2003. Black Sea impact on the formation of eastern Mediterranean sapropel S1? Evidence from the Marmara Sea. Palaeogeography, Palaeoclimatology, Palaeoecology 190, 9-21.

Stanley, D. J., \& Blanpied, C., 1980. Late Quaternary water exchange between the eastern Mediterranean and the Black Sea. Nature, 285(5766), 537.

Svensson, A., Andersen, K.K., Bigler, M., Clausen, H.B., Dahl-Jensen, D., Davies, S.M., Johnsen, S.J., Muscheler, R., Rasmussen, S.O., Röthlisberger, R., Steffensen, J.P., Vinther, B.M., 2006. The Greenland Ice Core Chronology 2005, 15-42 ka. Part 2: comparison to other records. Quaternary Science Reviews 25, 3258-3267.

Svensson, A., Andersen, K.K., Bigler, M., Clausen, H.B., Dahl-Jensen, D., Davies, S.M., Johnsen, S.J., Muscheler, R., Parrenin, F., Rasmussen, S.O., Röthlisberger, R., Seierstad, I., 
Steffensen, J.P., Vinther, B.M., 2008. A 60000 year Greenland stratigraphic ice core chronology. Climate of the Past 4, 47-57.

Svitoch, A. A., Selivanov, A. O. \& Yanina, T. A., 2000. Paleohydrology of the Black Sea Pleistocene basin. Wat. Resour. 27, 655-664 (2000).

Thomson, J., Higgs, N.C., Wilson, T.R.S., Croudace, I.W., De Lange, G.J., Van Santvoort, P.J.M., 1995. Redistribution and geochemical behaviour of redox-sensitive elements around S1, the most recent eastern Mediterranean sapropel, Geochimica et Cosmochimica Acta, 59, $17,3487-3501$.

Thomson, J., Croudace, I.W., Rothwell, R.G., 2006. A geochemical application of the ITRAX scanner to a sediment core containing eastern Mediterranean sapropel units, New Techniques in Sediment Core Analysis. In: Rothwell, R.G. (Ed.), Geological Society, London, Special Publications vol. 267.

Tryon, M. D., Henry, P., and Hilton, D. R., 2012. Quantifying submarine fluid seep activity along the North Anatolian Fault Zone in the Sea of Marmara. Marine Geology 315, 15-28.

Ünlülata, Ü., Oğuz, T., Latif, M.A., Özsoy, E., 1990. On the physical oceanography of the Turkish Straits. The Physical Oceanography of Sea Straits. Springer, Dordrecht, pp. 25-60.

Vardar, D., Öztürk, K., Yaltırak, C., Alpar, B., \& Tur, H., 2014. Late Pleistocene-Holocene evolution of the southern Marmara shelf and sub-basins: middle strand of the North Anatolian fault, southern Marmara Sea, Turkey. Marine Geophysical Research, 35(1), 69-85.

Vidal, L.,Ménot, G. Joly, C. Bruneton, H., Rostek, F., Çağatay, M.N., Major,M., and Bard, E., 2010. Hydrology in the Sea of Marmara during the last $23 \mathrm{ka}$ : Implications for timing of Black Sea connections and sapropel deposition. Paleoceanography, vol. 25 (1), pa1205, doi:10.1029/2009pa001735.

Weaver, P.P.E., Schultheis, P.J., 1990. Current methods for obtaininig, logging and splitting marine sediment cores. Mar. Geophys. Res. 12, 85-100.

Wegwerth, A., Dellwig, O., Kaiser, J., Ménot, G., Bard, E., Shumilovskikh, L., \& Arz, H. W. 2014. Meltwater events and the Mediterranean reconnection at the Saalian-Eemian transition in the Black Sea. Earth and planetary science letters, 404, 124-135. 
Wolff, E.W., Chappellaz, J., Blunier, T., Rasmussen, S.O., Svensson, A., 2010. Millennialscale variability during the last glacial: the ice core record. Quaternary Science Reviews 29, $2828-2838$.

Wulf, S., Brauer, A., Kraml, M., Keller, J., Negendank, J.F.W., 2004. Tephrochronology of the $100 \mathrm{ka}$ lacustrine sediment record of Lago Grande di Monticchio (southern Italy). Quaternary International $122,7-30$.

Ziegler, M., T. Jilbert, G. J. de Lange, L. J. Lourens, and G.-J. Reichart., 2008. Bromine counts from XRF scanning as an estimate of the marine organic carbon content of sediment cores, Geochem. Geophys. Geosyst., 9, Q05009, doi:10.1029/2007GC001932.

Zubakov, V. A., 1988. Climatostratigraphic scheme of the Black Sea Pleistocene and its correlation with the oxygen isotope scale and glacial events. Quaternary Research 29, 124. 


\section{Figure captions}

Fig. 1. (a) Location of the Sea of Marmara (SoM) and other sites discussed in the text: ODP977A in Western Mediterranean (Martrat et al., 2007), Deep core in Lake Ohrid (Francke et al., 2016; Sinopoli et al., 2018), core LC-21 south Aegean Sea (Grant et al., 2012), Sofular Cave in NW Anatolia (Fleitmann et al., 2009; Baderstcher et al, 2011) and core 22GC-8 in south Black Sea (Wegreth et al., 2014). (b) Bathymetric map of the (SoM) showing the location of the cores MRS-CS18 and MRS-CS27 (this study), MD01-2430 (Vidal et al., 2010; Çağatay et al., 2015; MD04-2745 (Çağatay et al., 2009) and MRS-CS22 (Kande et al., in review). (c, d) Chirp seismic profiles showing location of cores MRS-CS18_ and MRS-CS27 and the red seismic reflector surface of Sorlien et al. (2012) and Grall et al. (2013).

Fig. 2. Lithological logs of cores MRS-CS18 and MRS-CS27 (this study) and MRS-CS22 (Kande et al., in review), with their cross-correlation based on lithology and fossil content. Note the presence of sapropel units MSAP-1, MSAP-2, MSAP-3 and MSAP-4 with TOC contents greater than $2 \mathrm{wt} \%$ and the tephra units, MT-1 (Santorini, Cape Riva), MT-2 (Campanian Ignimbrite), MT-3 (unidentified) and MT-4 (unidentified), on core logs. For location of cores see Fig. 1b.

Fig. 3. Correlation of $\mu$-XRF Ca (x 1000 cps) of cores MRS-CS27 (b) and MRS-CS18 (c) tuned to GICC05 time scale of NGRIP ice core oxygen isotope data (a) (NGRIP, 2004; Svensson et al., 2008) (red) and synthetic NGRIP data (Barker et al., 2011) (black). Also for comparison are TOC data sets for cores MRS-CS18 (e) and MRS-CS27 (f) (this study) and for Lake Ohrid (d) (Francke et al., 2016). Note that the Marmara TOC data is plotted with NGRIP time scale, and Lake Ohrid TOC data are dated by tephrochronology and crosscorrelation of geochemical proxy data with orbital parameters. Numbers on NGRIP profile refers to Greenland interstadials (GI).

Fig. 4. Age-depth model for cores MRS-CS27 (a) and MRS-CS18 (b), constructed using Rstudio and the script "CLAM" (Blaauw, 2010). For a detailed description of the data used in modelling see text of sections 3.4.5 and 4.2.1 and Table S1 of Supplementary Data.

Fig. 5. Gamma density, magnetic susceptibility (MS) and $\mu$-XRF geochemical element and element-ratio profiles (K, Ca, Mn, Br, Zr, Ca/Ti, Fe/Mn, Sr/Ca, S/Ti, Br/TOC) for core MRSCS27. 
Fig. 6. Gamma density, magnetic susceptibility (MS) and $\mu$-XRF geochemical element and elemental ratio profiles (K, Ca, Mn, Br, Zr, Ca/Ti, Fe/Mn, $\mathrm{Sr} / \mathrm{Ca}, \mathrm{S} / \mathrm{T}$ ), $\mathrm{Br} / \mathrm{TOC}$ ) for core MRS-CS18. Note that $\mathrm{Br}$ in cps and TOC is in wt \% units.

Fig. 7. Chart showing the fossil content of core MRS-CS18.

Fig. 8. Comparison of SoM TOC and $\mu$-XRF Ca data for MIS5 and MIS6 from core MRSCS18 in the Sea of Marmara (a, b) with NGRIP $\delta^{13} \mathrm{O}$ data (NGRIP, 2004; Svensson et al., 2008; Barker et al., 2011) (c), sea level curve (Grant et al., 2012) (d), Black Sea TOC data (Wegreth et al., 2014) (e), $\delta^{13} \mathrm{O}$ speleothem data from Sofular in NW Anatolia (Baderstcher et al, 2011) (f), TOC and pollen data from Lake Ohrid (Francke et al., 2016; Sinopoli et al., 2018) (g, h), surface foraminiferal $\delta^{18} \mathrm{O}$ data from SE Aegean Sea core LC21 (Grant et al., 2012) (i), and sea surface temperature (SST) from Iberian margin core ODP-977A (Martrat et al., 2007) (j). The horizontal dashed lines show the present sill depths of Bosporus and Dardanelles straits at $-35 \mathrm{~m}$ and $-65 \mathrm{~m}$, respectively. SoM data tuned with GICC05 and synthetic time scales. All other data sets ware plotted using their original time scales.

\section{Supplementary Figure and Data}

Supplementary Fig. S1. Age-depth plot for cores MRS-CS27 (A) and MRS-CS18 (B), generated from correlation of $\mu$-XRF Ca (x $1000 \mathrm{cps}$ ) with Greenland Interstadials (GI) of NGRIP ice core oxygen isotope data (Svensson et al., 2008), tephrochronology, and the onset and end of Holocene Marmara sapropel for core MRS-CS27 (MSAP-1; Çağatay et al., 2015). For detailed description see text of sections 3.4.5 and 4.2.1 and Supplementary Data, Table 1). Supplementary Table S1. List of age data used for age-depth modelling for core MRS-CS27. Supplementary Table S2. List of age data used for age-depth modelling for core MRS-CS18. 

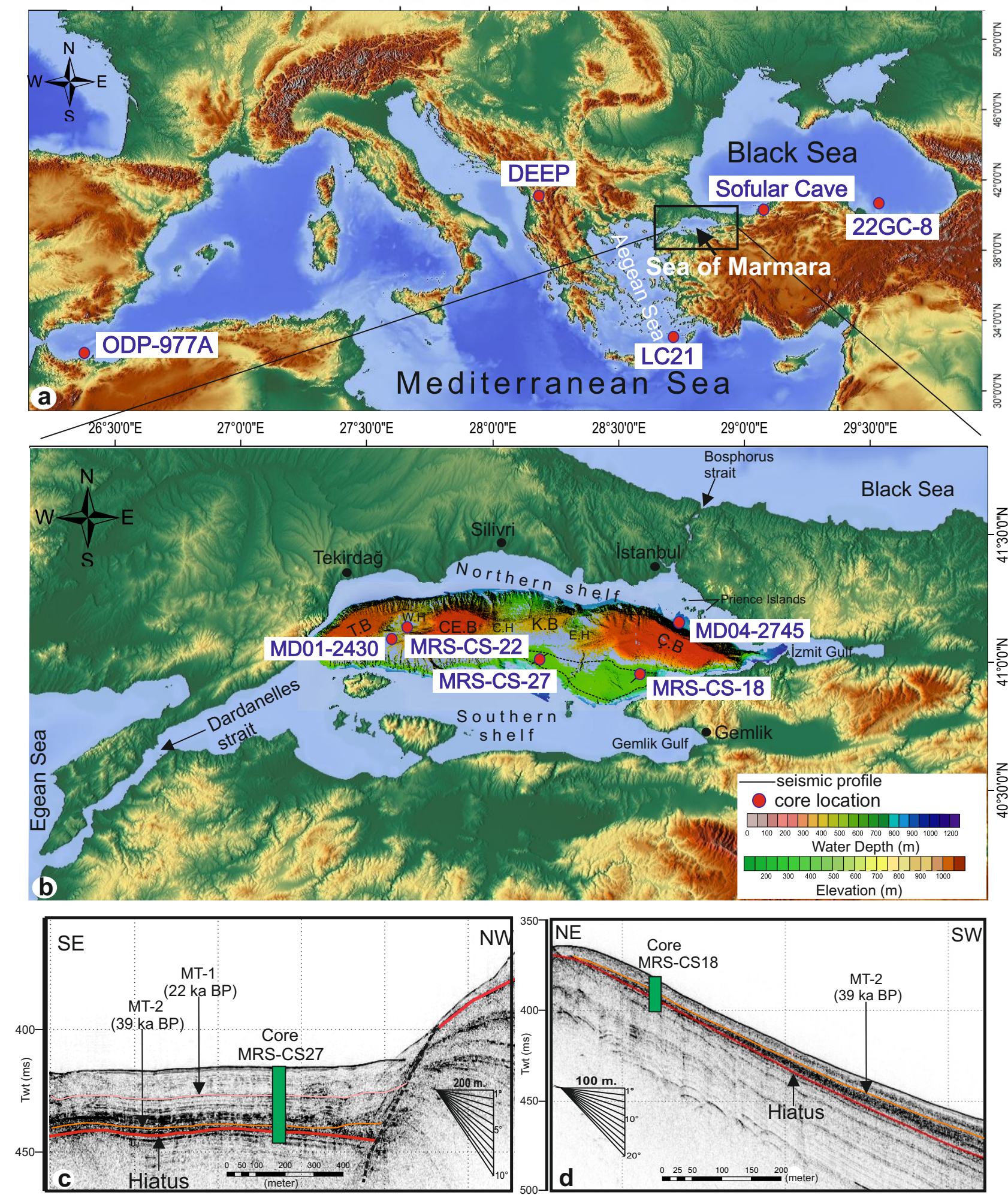

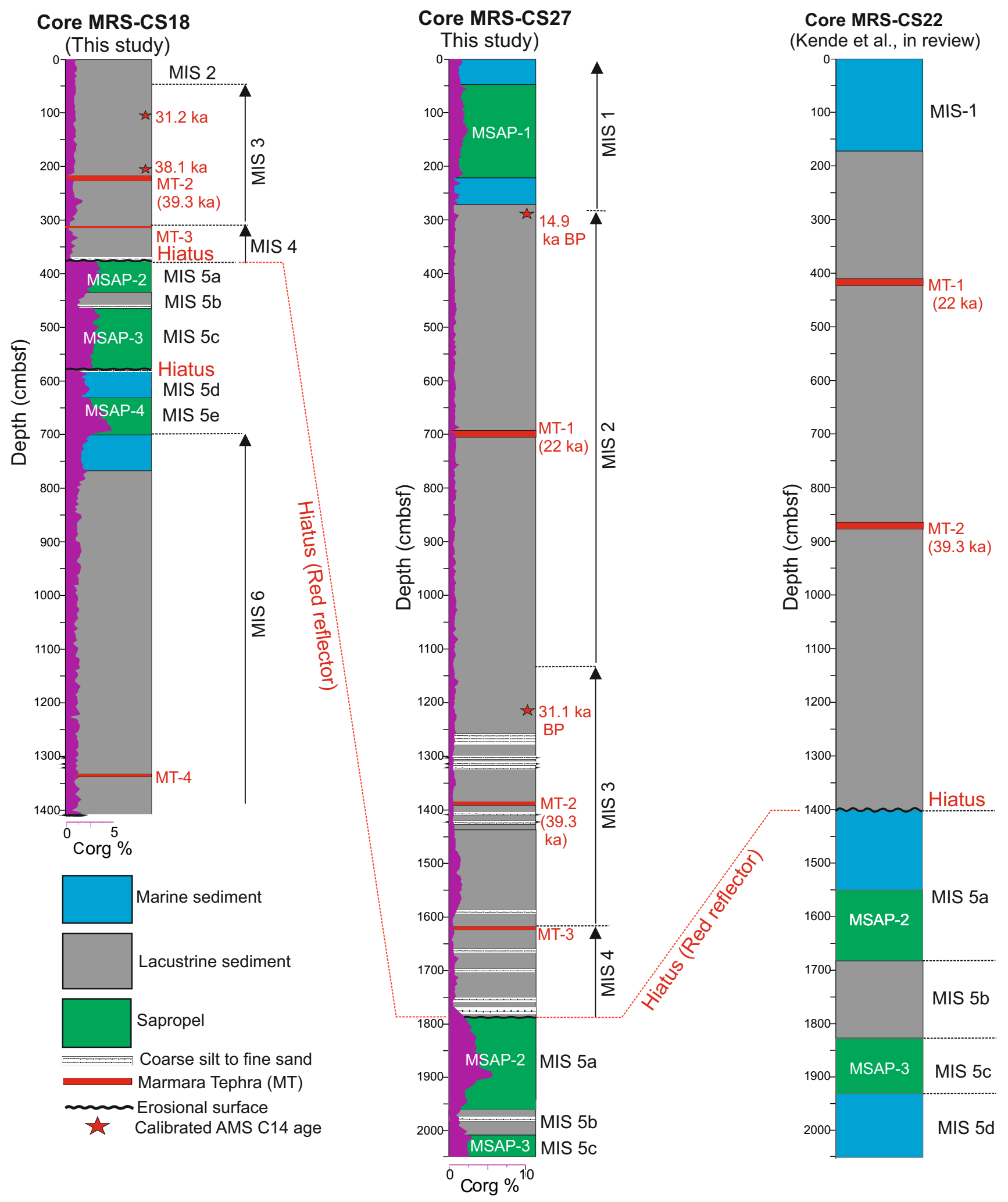


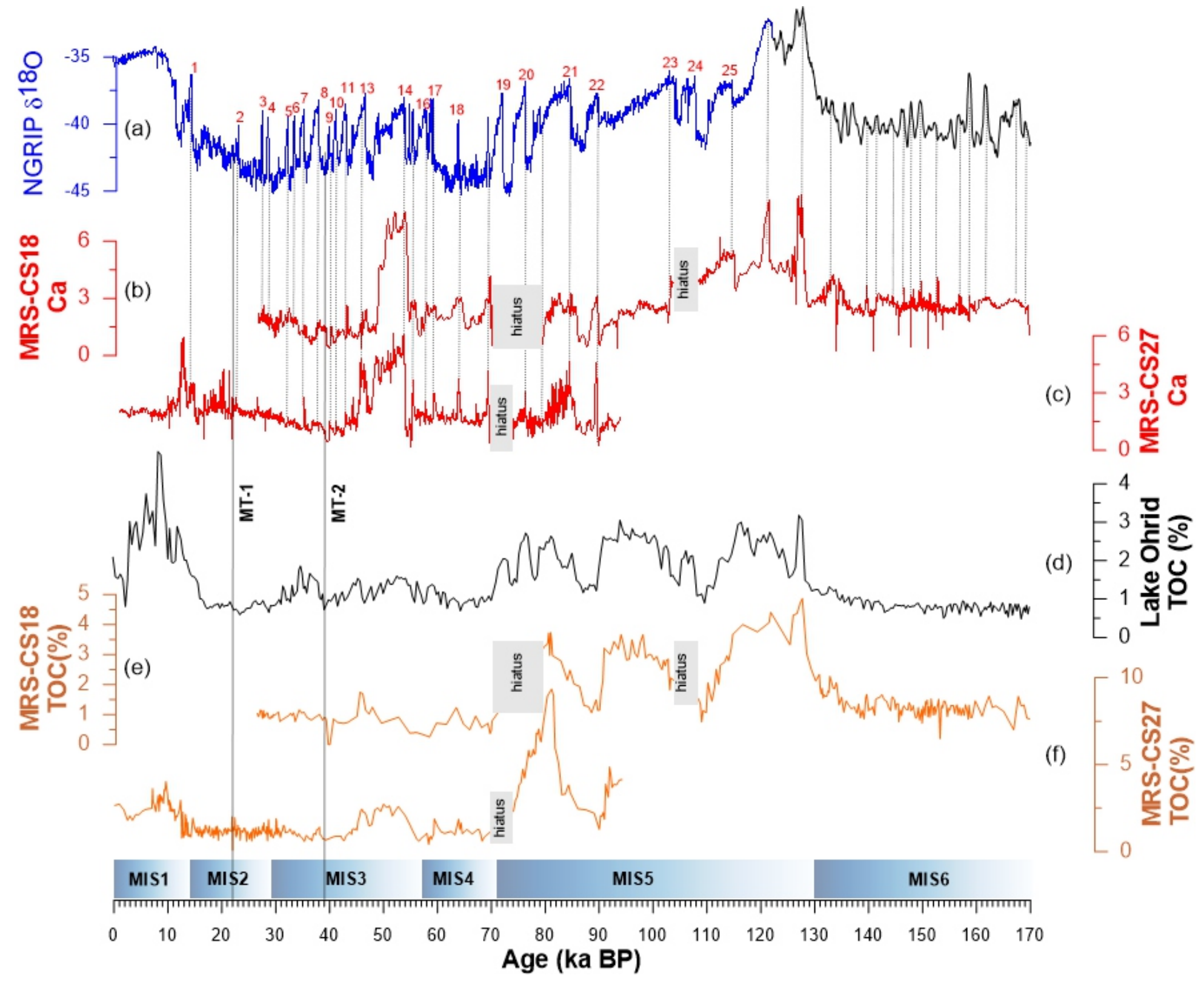



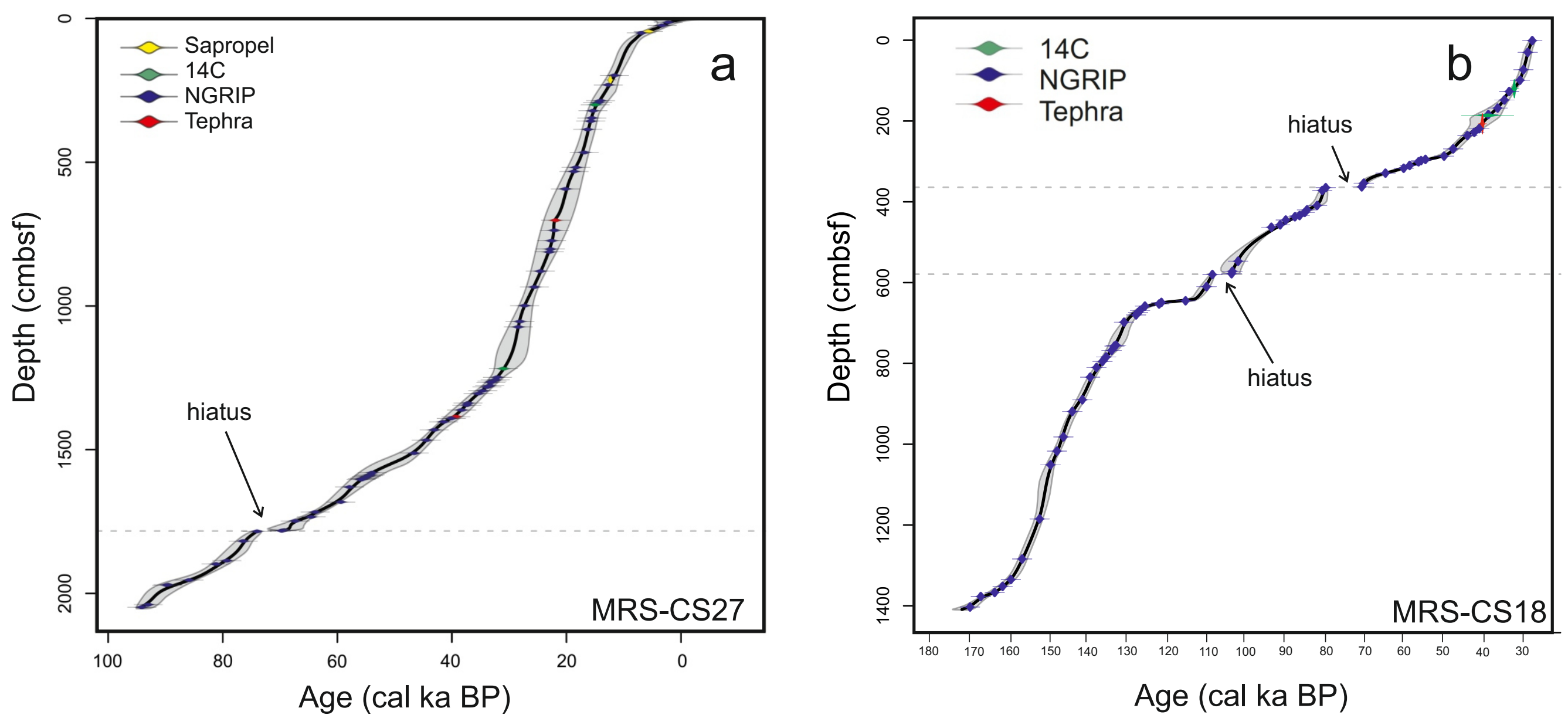


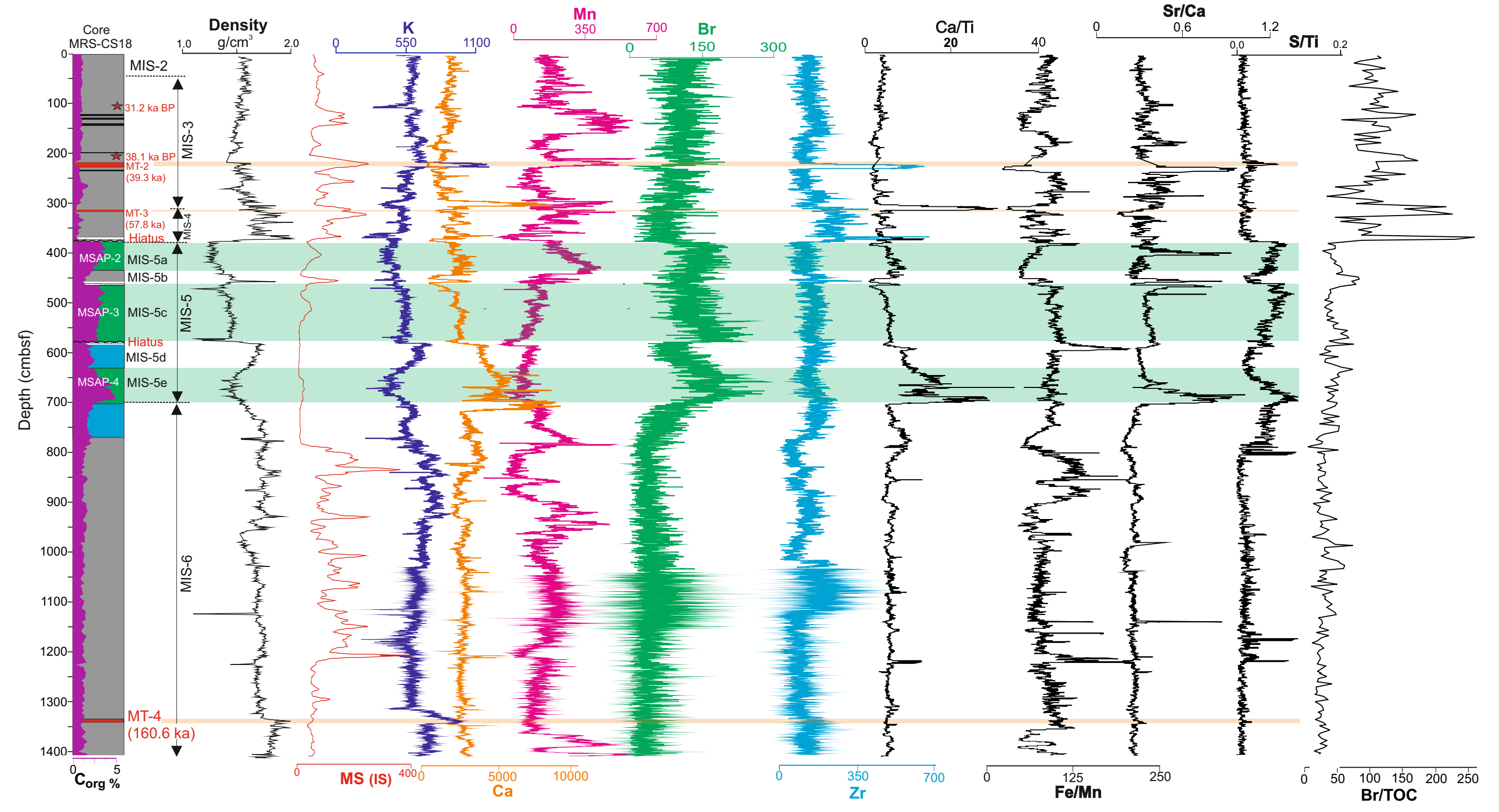




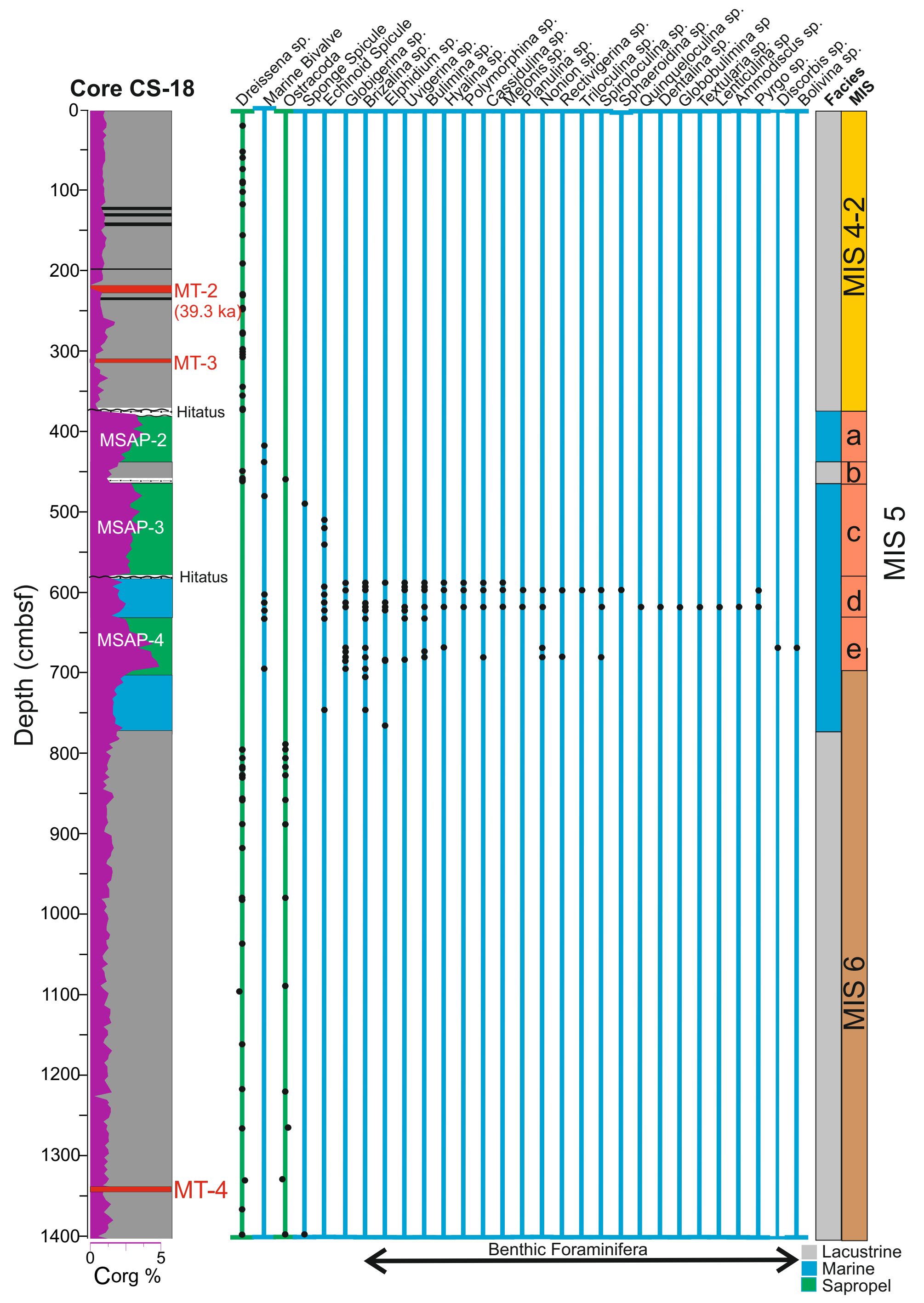




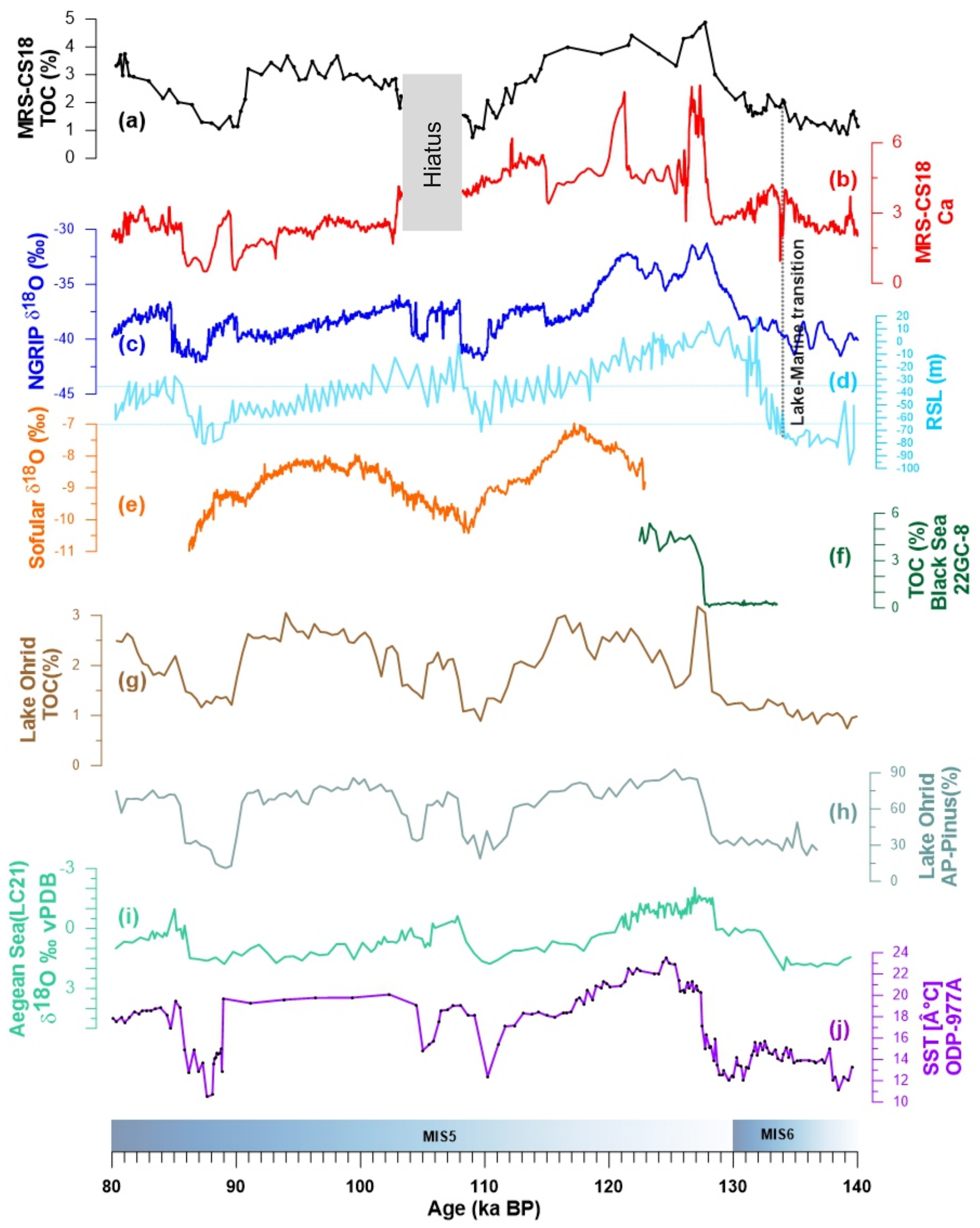


Table 1. Location, water depth and lengths of cores used in this study.

\begin{tabular}{|c|c|c|c|}
\hline Core ID & Latitude / Longitude & \multicolumn{1}{|c|}{$\begin{array}{c}\text { Water depth } \\
\text { (mbsl) }\end{array}$} & Core length (m) \\
\hline MRS-CS18 & $40^{\circ} 39,724^{\prime} / 28^{\circ} 52,775^{\prime}$ & 291 & 14,20 \\
\hline MRS-CS27 & $40^{\circ} 42,029^{\prime} / 28^{\circ} 24,053^{\prime}$ & 313 & 20,45 \\
\hline
\end{tabular}


Table 2. AMS radiocarbon and calibrated ages of fossil shell samples in the studied cores. INTCAL13 calibration curve of Reimer et al. (2013), with the respective reservoir ages of 400 and 1000 yrs for the latest marine and lacustrine units, are used for the calibration.

\begin{tabular}{cccc}
\hline $\begin{array}{c}\text { Sample No/Laboratory No/Dated } \\
\text { Material }\end{array}$ & $\begin{array}{c}\text { Core Depth } \\
\text { (cmbsf) }\end{array}$ & $\begin{array}{c}\text { Radiocarbon yrs } \\
\mathbf{\pm 2} \boldsymbol{\sigma} \text { error }\end{array}$ & $\begin{array}{c}\text { Calibrated age (yrs before } \\
\mathbf{1 9 5 0} \pm \mathbf{2} \boldsymbol{\sigma} \text { error) }\end{array}$ \\
\hline CS 27 S4/Poz-94035/Marine Bivalve & 300 & $13050 \pm 70 \mathrm{BP}$ & $14994 \pm 282 \mathrm{BP}$ \\
CS 27 S13/Poz-94036/Dreissena sp. & 1218 & $27820 \pm 260 \mathrm{BP}$ & $30933 \pm 345 \mathrm{BP}$ \\
CS 18 S3/Poz-97852/Dreissena sp. & 186 & $34.800 \pm 500 \mathrm{BP}$ & $37986 \pm 1336 \mathrm{BP}$ \\
CS18-S2-2/Poz-99211/Dreissena sp. & 120 & $28200 \pm 180$ & $31151 \pm 239 \mathrm{BP}$ \\
& & & \\
\hline
\end{tabular}


Supplementary Table S1. List of age data used for age-depth modelling for core MRS-CS27.

\begin{tabular}{|c|c|c|c|}
\hline $\begin{array}{l}\text { Core MRS- } \\
\text { CS27 Depth } \\
\text { (cmbs) }\end{array}$ & Age (ka BP) & MRS-CS27 Tuning & Error (yrs) \\
\hline 13.0206 & 2.2241 & NGRIP & \pm 500 \\
\hline 24.8145 & 3.3105 & NGRIP & \pm 500 \\
\hline 45 & 5.7 & Holocene Sapropel MSAP-1 top boundary & \pm 200 \\
\hline 50.0914 & 6.946 & NGRIP & \pm 500 \\
\hline 198.2669 & 11.6265 & NGRIP & \pm 500 \\
\hline 214 & 12.336 & Holocene SapropeMSAP-1 bottom boundary & \pm 200 \\
\hline 231.8089 & 12.6985 & NGRIP & \pm 500 \\
\hline 286.1079 & 14.0596 & NGRIP & \pm 500 \\
\hline 293.6676 & 14.5637 & NGRIP & \pm 500 \\
\hline 300 & 14.986 & AMS C-14 & \pm 282 \\
\hline 321.5262 & 15.3764 & NGRIP & \pm 500 \\
\hline 346.8762 & 15.5684 & NGRIP & \pm 500 \\
\hline 357.2467 & 15.7603 & NGRIP & \pm 500 \\
\hline 386.8499 & 16.2919 & NGRIP & \pm 500 \\
\hline 466.189 & 16.8934 & NGRIP & \pm 500 \\
\hline 518.2786 & 18.331 & NGRIP & \pm 500 \\
\hline 532.7459 & 18.6814 & NGRIP & \pm 500 \\
\hline 593.52 & 20.1926 & NGRIP & \pm 500 \\
\hline 695.5 & 21.97 & MT-1 / CapeRiva & \pm 875 \\
\hline 702.5 & 21.97 & MT-1 / CapeRiva & \pm 500 \\
\hline 737.7064 & 22.0991 & NGRIP & \pm 500 \\
\hline 773.6003 & 22.5943 & NGRIP & \pm 500 \\
\hline 802.0809 & 22.7951 & NGRIP & \pm 500 \\
\hline 812.1484 & 22.996 & NGRIP & \pm 500 \\
\hline 879.6157 & 24.5596 & NGRIP & \pm 500 \\
\hline 934.7341 & 25.6018 & NGRIP & \pm 500 \\
\hline 999.8269 & 27.3106 & NGRIP & \pm 500 \\
\hline 1054.9304 & 28.121 & NGRIP & \pm 500 \\
\hline 1073.3632 & 28.4057 & NGRIP & \pm 500 \\
\hline 1218 & 30.997 & AMS C-14 & \pm 345 \\
\hline 1248.5848 & 32.0503 & NGRIP & \pm 500 \\
\hline 1257.0862 & 32.448 & NGRIP & \pm 500 \\
\hline 1262.9913 & 32.9996 & NGRIP & \pm 500 \\
\hline 1266.8784 & 33.1892 & NGRIP & \pm 500 \\
\hline 1277.2319 & 33.3961 & NGRIP & \pm 500 \\
\hline 1282.6721 & 33.8837 & NGRIP & \pm 500 \\
\hline 1295.8881 & 34.6037 & NGRIP & \pm 500 \\
\hline 1305.4955 & 35.4277 & NGRIP & \pm 500 \\
\hline 1338.7875 & 37.1945 & NGRIP & \pm 500 \\
\hline 1345.5629 & 37.4014 & NGRIP & \pm 500 \\
\hline 1362.2 & 38.3138 & NGIP & \pm 501 \\
\hline 1380 & 39.29 & MT-2 / Cl & \pm 220 \\
\hline 1391.066 & 40.1028 & NGRIP & \pm 500 \\
\hline 1403.0797 & 41.4411 & NGRIP & \pm 500 \\
\hline 1431.2446 & 43.0867 & NGRIP & \pm 500 \\
\hline 1467.7705 & 44.4819 & NGRIP & \pm 500 \\
\hline 1512.6478 & 46.5942 & NGRIP & \pm 500 \\
\hline 1580.0028 & 53.912 & NGRIP & \pm 500 \\
\hline 1587.5947 & 54.2751 & NGRIP & \pm 500 \\
\hline 1591.6759 & 54.5352 & NGRIP & \pm 500 \\
\hline 1594.1202 & 54.9398 & NGRIP & \pm 500 \\
\hline 1598.0842 & 55.251 & NGRIP & \pm 500 \\
\hline 1601.5571 & 55.6171 & NGRIP & \pm 500 \\
\hline 1604.5709 & 55.8423 & NGRIP & \pm 500 \\
\hline 1630.9403 & 57.8711 & NGRIP & \pm 500 \\
\hline 1682.8348 & 59.3881 & NGRIP & \pm 500 \\
\hline 1717.8228 & 63.8576 & NGRIP & \pm 500 \\
\hline 1734.0916 & 64.5648 & NGRIP & \pm 500 \\
\hline 1748.6082 & 67.3582 & NGRIP & \pm 500 \\
\hline 1780.0782 & 69.2394 & NGRIP & \pm 500 \\
\hline 1781.8718 & 69.5541 & NGRIP & \pm 500 \\
\hline 1783.8556 & 69.7082 & NGRIP & \pm 500 \\
\hline 1783.8556 & 74.0168 & NGRIP & \pm 500 \\
\hline 1818.9065 & 76.421 & $\mathrm{GI}-20$ & \pm 500 \\
\hline 1886.9027 & 79.2933 & NGRIP & \pm 500 \\
\hline 1898.8105 & 81.1672 & NGRIP & \pm 500 \\
\hline 1954.3132 & 84.6397 & NGRIP & \pm 500 \\
\hline 1970.4138 & 89.5617 & NGRIP & \pm 500 \\
\hline 1971.5031 & 89.7805 & NGRIP & \pm 500 \\
\hline 2039.5179 & 93.017 & NGRIP & \pm 500 \\
\hline 2048.9858 & 94.119 & NGRIP & \pm 500 \\
\hline
\end{tabular}


Supplementary Table S2. List of age data used for age-depth modelling for core MRS-CS18.

\begin{tabular}{|c|c|c|c|}
\hline $\begin{array}{l}\text { Core MRS- } \\
\text { CS18 Depth } \\
\text { (cmbsf) }\end{array}$ & $\begin{array}{c}\text { Age } \\
\text { (ka BP) }\end{array}$ & $\begin{array}{l}\text { MRS-CS18 } \\
\text { Tuning }\end{array}$ & $\begin{array}{c}\text { Error } \\
\text { (yrs) }\end{array}$ \\
\hline 0 & 26.565 & NGRIP & \pm 500 \\
\hline 30.1818 & 27.7271 & NGRIP & \pm 500 \\
\hline 73.1091 & 28.8272 & NGRIP & \pm 500 \\
\hline 99.1648 & 29.6974 & NGRIP & \pm 500 \\
\hline 120 & 31.15 & AMS C-14 & \pm 243 \\
\hline 126.8581 & 32.4647 & NGRIP & \pm 500 \\
\hline 148.0583 & 33.6912 & NGRIP & \pm 500 \\
\hline 168.206 & 35.4018 & NGRIP & \pm 500 \\
\hline 183.8221 & 37.7844 & NGRIP & \pm 500 \\
\hline 186.33 & 37.98 & AMS C-14 & \pm 1336 \\
\hline 207 & 39.29 & $\mathrm{MT}-2$ / Cl & \pm 220 \\
\hline 219.3219 & 40.128 & NGRIP & \pm 500 \\
\hline 228.1379 & 41.373 & NGRIP & \pm 500 \\
\hline 235.5979 & 43.124 & NGRIP & \pm 500 \\
\hline 268.6144 & 46.758 & NGRIP & \pm 500 \\
\hline 287.1655 & 49.0847 & NGRIP & \pm 500 \\
\hline 294.6209 & 53.8385 & NGRIP & \pm 500 \\
\hline 298.3314 & 54.9614 & NGRIP & \pm 500 \\
\hline 300.8764 & 55.5996 & NGRIP & \pm 500 \\
\hline 309.9868 & 57.872 & NGRIP & \pm 500 \\
\hline 316.8299 & 59.3936 & NGRIP & \pm 500 \\
\hline 329.4534 & 64.04 & NGRIP & \pm 500 \\
\hline 354.103 & 69.5822 & NGRIP & \pm 500 \\
\hline 365.0348 & 70.1013 & NGRIP & \pm 500 \\
\hline 365.0348 & 79.2859 & NGRIP & \pm 500 \\
\hline 371.8365 & 80.1732 & NGRIP & \pm 500 \\
\hline 409.0202 & 81.487 & NGRIP & \pm 500 \\
\hline 419.8139 & 84.0956 & NGRIP & \pm 500 \\
\hline 425.5263 & 84.6229 & NGRIP & \pm 500 \\
\hline 433.8723 & 85.9605 & NGRIP & \pm 500 \\
\hline 436.8213 & 87.1536 & NGRIP & \pm 500 \\
\hline 445.1759 & 89.505 & NGRIP & \pm 500 \\
\hline 463.0285 & 93.1703 & NGRIP & \pm 500 \\
\hline 507.6761 & 102.9912 & NGRIP & \pm 500 \\
\hline 546.4614 & 104.9419 & NGRIP & \pm 500 \\
\hline 571.6031 & 107.8328 & NGRIP & \pm 500 \\
\hline 644.6536 & 115.0722 & NGRIP & \pm 500 \\
\hline 649.2014 & 121.2392 & NGRIP & \pm 500 \\
\hline 652.8528 & 121.8265 & NGRIP & \pm 500 \\
\hline 657.8588 & 125.4377 & NGRIP & \pm 500 \\
\hline 669.2298 & 126.683 & NGRIP & \pm 500 \\
\hline 673.6564 & 127.1884 & NGRIP & \pm 500 \\
\hline 679.5131 & 127.703 & NGRIP & \pm 500 \\
\hline 698.0534 & 130.778 & NGRIP & \pm 500 \\
\hline 754.7751 & 132.8093 & NGRIP & \pm 500 \\
\hline 756.5239 & 133.215 & NGRIP & \pm 500 \\
\hline 768.3281 & 133.9528 & NGRIP & \pm 500 \\
\hline 784.3008 & 135.3462 & NGRIP & \pm 500 \\
\hline 794.9094 & 136.2634 & NGRIP & \pm 500 \\
\hline 809.7576 & 137.8126 & NGRIP & \pm 500 \\
\hline 834.1352 & 139.4234 & NGRIP & \pm 500 \\
\hline 889.7019 & 141.4122 & NGRIP & \pm 500 \\
\hline 918.7632 & 143.9839 & NGRIP & \pm 500 \\
\hline 981.9744 & 146.2562 & NGRIP & \pm 500 \\
\hline 1016.5611 & 147.8962 & NGRIP & \pm 500 \\
\hline 1051.2035 & 149.5388 & NGRIP & \pm 500 \\
\hline 1184.5349 & 152.3341 & NGRIP & \pm 500 \\
\hline 1283.9761 & 156.7821 & NGRIP & \pm 500 \\
\hline 1335.146 & 159.671 & NGRIP & \pm 500 \\
\hline 1351.6365 & 161.7748 & NGRIP & \pm 500 \\
\hline 1367.4624 & 163.7924 & NGRIP & \pm 500 \\
\hline 1377.0304 & 167.3428 & NGRIP & \pm 500 \\
\hline 1394.4 & 169,186 & NGRIP & \pm 500 \\
\hline
\end{tabular}


Age ka (BP)

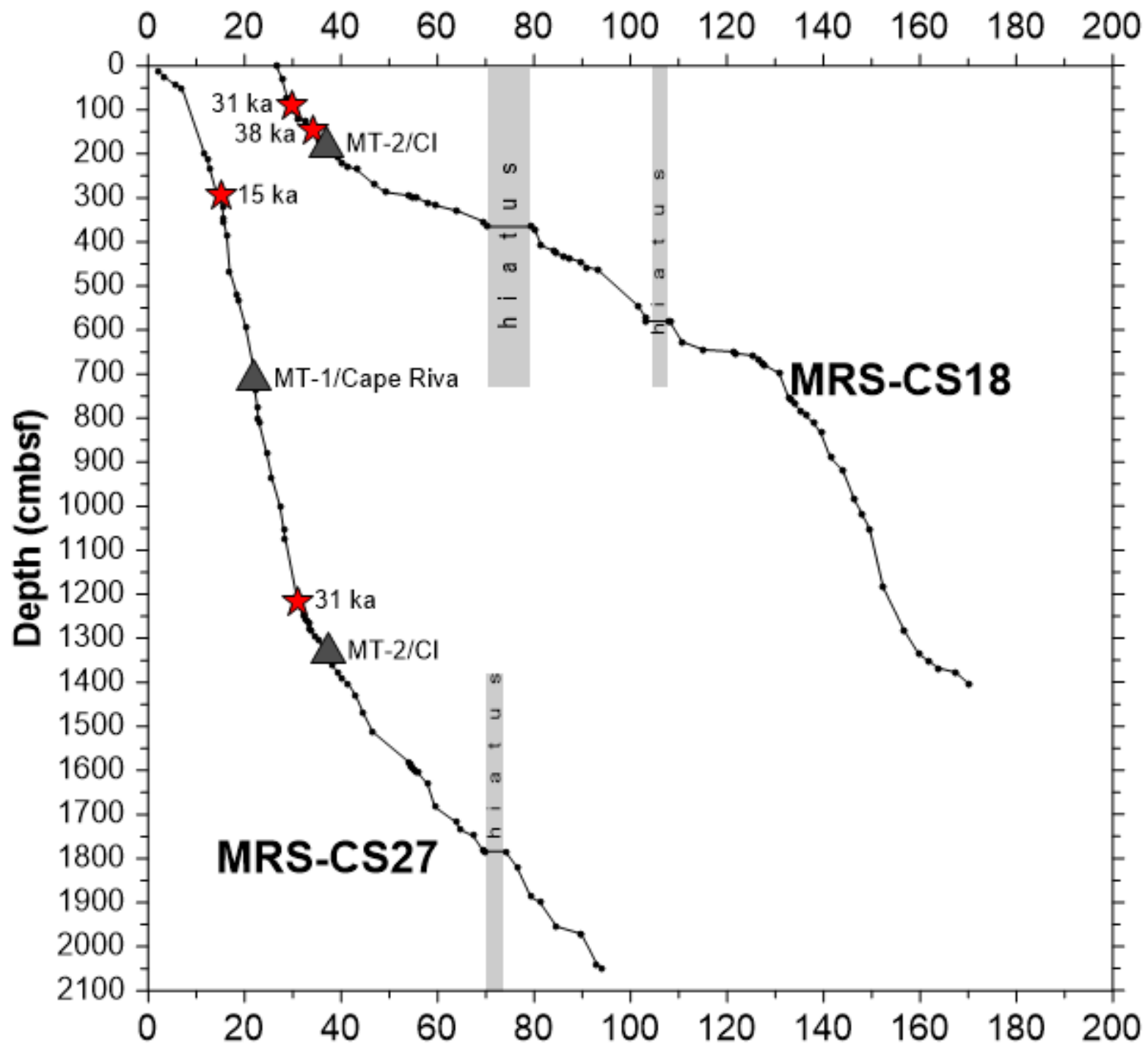

Supplementary Fig. S1. Age-depth plot for cores MRS-CS27 (A) and MRS-CS18 (B), generated from correlation of $\mu$-XRF Ca (x $1000 \mathrm{cps}$ ) with Greenland Interstadials (GI) of NGRIP ice core oxygen isotope data (Svensson et al., 2008), tephrochronology, and the onset and end of Holocene Marmara sapropel for core MRS-CS27 (MSAP-1; Çağatay et al., 2015). For detailed description see text of sections 3.4.5 and 4.2.1 and Supplementary Data, Table 1). 